\title{
The Genetic Basis of Tomato Aroma
}

\author{
Matteo Martina ${ }^{1}\left(\mathbb{D}\right.$, Yury Tikunov ${ }^{2}\left(\mathbb{D}\right.$, Ezio Portis ${ }^{1, *(\mathbb{D})}$ and Arnaud G. Bovy ${ }^{2, *(\mathbb{D})}$ \\ 1 DISAFA, Plant Genetics and Breeding, University of Turin, 10095 Grugliasco, Italy; matteo.martina@unito.it \\ 2 Plant Breeding, Wageningen University \& Research, P.O. Box 386, 6700 AJ Wageningen, The Netherlands; \\ yury.tikunov@wur.nl \\ * Correspondence: ezio.portis@unito.it (E.P.); arnaud.bovy@wur.nl (A.G.B.); \\ Tel.: +39-011-6708807 (E.P.); +31-317-480762 (A.G.B.)
}

check for updates

Citation: Martina, M.; Tikunov, Y.; Portis, E.; Bovy, A.G. The Genetic Basis of Tomato Aroma. Genes 2021, 12, 226. https://doi.org/10.3390/ genes12020226

Academic Editor: Mathilde Causse Received: 13 January 2021

Accepted: 1 February 2021

Published: 4 February 2021

Publisher's Note: MDPI stays neutral with regard to jurisdictional claims in published maps and institutional affiliations.

Copyright: (c) 2021 by the authors. Licensee MDPI, Basel, Switzerland. This article is an open access article distributed under the terms and conditions of the Creative Commons Attribution (CC BY) license (https:/ / creativecommons.org/licenses/by/ $4.0 /)$.

\begin{abstract}
Tomato (Solanum lycopersicum L.) aroma is determined by the interaction of volatile compounds (VOCs) released by the tomato fruits with receptors in the nose, leading to a sensorial impression, such as "sweet", "smoky", or "fruity" aroma. Of the more than 400 VOCs released by tomato fruits, 21 have been reported as main contributors to the perceived tomato aroma. These VOCs can be grouped in five clusters, according to their biosynthetic origins. In the last decades, a vast array of scientific studies has investigated the genetic component of tomato aroma in modern tomato cultivars and their relatives. In this paper we aim to collect, compare, integrate and summarize the available literature on flavour-related QTLs in tomato. Three hundred and fifty nine (359) QTLs associated with tomato fruit VOCs were physically mapped on the genome and investigated for the presence of potential candidate genes. This review makes it possible to (i) pinpoint potential donors described in literature for specific traits, (ii) highlight important QTL regions by combining information from different populations, and (iii) pinpoint potential candidate genes. This overview aims to be a valuable resource for researchers aiming to elucidate the genetics underlying tomato flavour and for breeders who aim to improve tomato aroma.
\end{abstract}

Keywords: tomato; S. lycopersicum; aroma; volatiles; QTLs

\section{Introduction}

Tomato (Solanum lycopersicum L.) is one of the most important crops on the market, used worldwide as basis in many national traditional dishes [1]. Conventional wisdom suggests that breeding tends to reduce the genetic basis of a cultivated species, but tomato genetic diversity appears to have actually been enhanced in the last fifty years. A recent study [2] investigated the genetic diversity of cultivated tomato varieties in The Netherlands (NL) from 1950s to 2010s, observing that tomato commercial varieties from 1950s and 1960s were mainly homozygous, with narrow genetic variation among them. From 1970s onwards, genetic diversity in tomato has increased, thanks to the application of introgression breeding programs using wild relatives of tomato. The first genetic diversity boost appeared to take place with the introgression of tomato mosaic virus (ToMV), southern root-knot nematode (Meloidogyne incognita) and leaf mold disease (Cladosporium fulvum) resistance from Solanum peruvianum and Solanum pimpinellifolium [3-5]. These introgressions varied in size from $\sim 5 \%$ of the chromosome (introgression of Cf- 4 and Cf-9 on top of Chr.01 for resistance to Cladosporium fulvum) up to half a chromosome 9 (ToMV), and together led to a significant increase in overall genetic diversity [2]. A second diversity boost, starting in the late 1980s affected both fruit size and quality traits: in particular the introgression of parts of Chr. 4, 5 and 12 from S. pimpinellifolium led to fruit size variation among cultivated varieties and the introduction of cherry, cocktail and large fruited varieties to the NL market [3].

Not only disease resistance and fruit size, but also flavour has been targeted by breeding programs in the last thirty years [2]. The main components of tomato fruit 
flavour are: (i) sweetness, mainly determined by sugars; (ii) acidity, determined by the presence of organic acids; (iii) textural attributes, such as firmness and juiciness, and (v) aroma [6]. Tomato aroma is determined by the interaction of volatile compounds released by the tomato fruits with receptors in our nose, leading to a sensorial impression, such as "sweet", "smoky", or "fruity" aroma. More than 400 volatile compounds [7] have been detected in ripe tomato fruit and they are derived from primary metabolites, such as fatty acids and amino acids or secondary metabolites, such as phenylpropanoids and carotenoids. Only a fraction of these volatiles has been associated with specific human sensorial attributes or were shown to be present at concentrations above the so-called odor threshold. From an evolutionary point, these molecules evolved to attract seed dispersers, including animals and men. For humans they have a great economic impact, since they are important determinants of food quality and consumer preference $[8,9]$. Among them, about 20 compounds have been identified as the most contributing ones, based on their concentrations in fruits and their individual odor thresholds [10]. However, it has to be mentioned that the perception of aroma is determined by both the odor activity of individual VOCs and by interactions between them or with other non-volatile chemicals [11]. For instance, the presence of sugars or organic acids alters the perception of aromatic descriptors of samples with the same concentration of volatiles [12,13], while the perception of basic tastes, e.g., sourness or sweetness, can be modified by variation in VOCs accumulation $[8,14,15]$. Tomato aroma is therefore a hard-to-define trait and efforts have been made to develop prediction models for its different components $[8,12,16,17]$. This led to the identification of the main 21 VOCs impacting consumer liking (Table 1). Each of these compounds has its own characteristic odor, as retrieved from the Good Scents Company database [18]. The compounds can be grouped in five clusters, according to their biosynthetic origins [11]: (1) fatty acids-derived VOCs; (2) sulphur-containing and branched chain amino acids-derived VOCs; (3) carotenoid catabolism by-product phenolic VOCs; (4) phenolic VOCs; and (5) phenylpropanoid VOCs [19-25].

Table 1. Overview of the 21 main components of tomato aroma (adapted from [11]). * Odor descriptors were retrieved from the Good Scents Company database [18].

\begin{tabular}{lll}
\hline Class & Compound & Odor Descriptors * \\
\hline Apocarotenoid & 6-Methyl-5-hepten-2-one & Citrus, green, musty, lemongrass, apple \\
Apocarotenoid & Geranial & Sharp, lemon, sweet \\
Apocarotenoid & ß-Damascenone & Apple, rose, honey, tobacco, sweet \\
Apocarotenoid & Geranylacetone & Fresh, green, fruity, waxy, rose, woody, magnolia, tropical \\
Apocarotenoid & 3-Ionone & Floral, woody, sweet, fruity, berry, tropical, beeswax \\
BCAA & 3-Methylbutanal & Ethereal, aldehydic, chocolate, peach, fatty \\
BCAA & 2-Methylbutanal & Musty, cocoa, coffee, nutty \\
BCAA & 3-Methylbutanol & Fusel, oil, alcoholic, whiskey, fruity, banana \\
BCAA & 2-Isobuthylthiazole & Green, wasabi, privet, tomato, leaf, earthy, vegetable, metallic \\
Lipid & 1-Penten-3-one & Pungent, peppery, mustard, garlic, onion \\
Lipid & (Z)-3-Hexenal & Green, fatty, grassy, weedy, fruity, apple \\
Lipid & Hexenal & Sweet, almond, fruity, green, leafy, apple, plum, vegetable \\
Lipid & (E)-2-Hexenal & Sharp, fresh, leafy, green, clean, fruity, spicy, herbal \\
Lipid & (E)-2-Heptenal & Pungent, green, vegetable, fresh, fatty \\
Lipid & (E,E)-2.4-Decadienal & Oily, cucumber, melon, citrus, pumpkin, nut, meat \\
Phenolic & Phenylacetaldehyde & Green, sweet, floral, hyacinth, clover, honey, cocoa \\
Phenolic & 2-Phenylethanol & Sweet, floral, fresh, bready, rose, honey \\
Phenolic & 1-Nitro-2-phenylethane & Flower, spice \\
Phenylpropanoid & Guaiacol & Phenolic, smoke, spice, vanilla, woody \\
Phenylpropanoid & Methyl salicylate & Wintergreen, mint \\
Phenylpropanoid & Eugenol & Sweet, spicy, clove, woody \\
\hline
\end{tabular}

Breeders and breeding researchers aim to elucidate the genetic basis underlying important agronomic traits. This requires three essential elements: (1) genetic variation, (2) phenotypic variation and (3) methods to find associations between the genetic and 
phenotypic data. As outlined in more detail below, advances in the development of highthroughput (HTP) molecular marker platforms, the availability of genomic information and progress in phenotyping methodologies, such as metabolomics, have led to an increasing importance and use of marker-assisted breeding strategies, such as QTL analysis, association mapping and genomic prediction in current plant breeding practice and transformed plant breeding into a hight-tech industry.

Marker-assisted introgression breeding: Tomato is highly autogamous, a characteristic that, together with the loss of many genes and alleles during domestication and crop improvement, led to a narrow genetic basis of cultivated tomato, compared with its 12 wild relative species [26]. For this reason, wild relatives have been used as potential sources of lost alleles in the development of new cultivated tomato varieties [27,28]. Marker-assisted selection in plant breeding programs relies on genetic linkage analyses, which are based on the principle of genetic recombination during meiosis. This allows the construction of linkage maps, composed of genetic markers linked to genes or Quantitative Trait Loci (QTL's) affecting traits of interest for a specific population. QTL analysis is mostly done using biparental segregating populations based on a cross of two contrasting genotypes. In order to discover and elucidate the genetic basis of agricultural traits, segregating populations have not only been made from intraspecific crosses, but also from interspecific crosses with various tomato wild relatives (S. pimpinellifolium, S. pennellii, S. lycopersicoides and S. habrochaites) in which genomic regions of the wild donor have been introgressed in the cultivated tomato genetic background, allowing the identification of potential new alleles for traits of interest [29-33]. Interestingly, researchers not only investigated Solanum lycopersicum wild relatives, but also Solanum lycopersicum var. cerasiforme L, the expected ancestor of the domesticated tomato [34].

The impact of genomics: In the last decades, the advances in genomics have provided new tools for discovering and tagging novel alleles and genes. The advent of next generation sequencing (NGS) techniques has considerably accelerated and simplified the genomewide detection of single-nucleotide polymorphisms (SNPs), which have become the most popular molecular markers. The development of the reference tomato genome from the inbred cultivar "Heinz 1706" [35] represented a milestone in the genomic era. The comparison of the cultivated tomato genome with the genome of a wild relative S. pimpinellifolium revealed the potential of high-throughput sequencing in comparative genetics, confirming the previously reported introgression of S. pimpinellifolium in the "Heinz 1706" genome [36] and the identification of thousands of SNPs between the two relatives. Further genome and transcriptome resequencing aimed at detecting genetic variation in tomato paved the way for the development of relatively universal genotyping platforms (i.e., SNP arrays) that can be applied for the genetic analyses of different populations-the SolCap SNParray $[37,38]$ and the CBSG array [3]. A further progress in the application of NGS is represented by the genotyping-by-sequencing (GBS) approaches, based on the use of restriction enzymes to decrease genome complexity before sequencing. These techniques include over a dozen of reduced-representation sequencing (RRS) approaches [39] and have been recently applied for high-resolution QTL mapping in tomato, especially in interspecific crosses [40-43]. These protocols have been applied in the development of high-density genetic maps in many different species [44-55], making it possible to perform comparative and quantitative genetics in virtually any genomic background. The current advances in genome sequencing technologies, such as a revolutionary increase of sequencing throughput and concomitant reduction in costs per sequenced nucleotide, allowed to unravel the genetic variation in tomato to its full extent $[25,56,57]$ and has helped to realize that the concept of one or a few reference genomes is not sufficient to fully understand the genetic control of traits. For this reason, the pangenome concept has been introduced in plant genomics, investigating the sum of genes that can be found in a specific species [58-63]. Specifically, the pangenome is defined as "the full complement of genes of a species, which can be partitioned into a set of core genes that are shared by all individuals and a set of dispensable genes that are partially shared or individual specific" [64]. In the Solanaceae family, the pangenomes of tomato and 
pepper (Capsicum spp.) have been recently released, identifying missing genes involved in resistance mechanisms and quality traits $[26,65,66]$, but eggplant (Solanum melongena L.) and potato (Solanum tuberosum L.) are still pangenome-orphan species. The availability of the tomato pangenome allowed the identification of presence/absence variations (PAVs) and the identification of structural variants (SVs) of functionally important genes $[26,65]$. Interestingly, [26] identified a rare promoter allele for the TomLoxC gene, a lipoxygenase that has been reported to be crucial in C5 and C6 lipid-derived volatiles biosynthesis and apocarotenoid production $[67,68]$. Moreover, the newly developed tomato pangenome [65] resolved the genomic region flanking NSGT1, a functional gene associated with the production of guaiacol, methylsalicylate and eugenol, three phenylalanine-derived volatiles. Five different haplotypes were identified in the analyzed tomato germplasm, providing new insights in the understanding of the genetic variation of NSGT1. Pangenome appears to be the most novel tool that breeders and researchers have at their disposal: it may facilitate the mining of natural genetic variation and could contribute to crop improvement by supporting molecular breeding programs and gene function studies.

Linking genetic markers to traits: In the genomics era, novel genotyping techniques and the availability of multitudes of molecular markers, in combination with new highthroughput phenotyping technologies (i.e., phenotyping platforms), supported the development of new methodologies to link genetic markers to phenotypic traits. Not only the above-mentioned QTL mapping has become more precise, also association mapping and genomic prediction are now widely used in breeding [69-72]. Genome-Wide Association Studies (GWASs) are based on genotyping of a set of accessions representing the variability in a given species and rely on the linkage disequilibrium (LD) between a marker and its associated trait [73]. This technique has been applied in tomato, identifying interesting associations for many fruit quality traits [74-79]. Zhao et al. performed a meta-GWAS analysis, by combining datasets of several GWAS panels. This analysis not only led to confirmation of existing, but also to the discovery of novel QTLs and candidate genes for several flavour-related traits [77]. Genomic Prediction (GP) is a selection tool that makes use of genetic markers to predict the genetic potential of untested lines in breeding [80]. While QTL mapping and GWAS rely on the (statistically-significant) association between phenotypic variation and specific molecular markers, GP calculates the genetic potential of breeding candidates by the application of Bayesian or mixed statistical models that take all the genome-wide marker information into account to predict the phenotype. Genomic prediction is a selection tool rather than a research tool and performs better with traits that are controlled by a large number of small-effect QTLs which are hard to detect by QTL analysis of mapping populations or GWAS [81,82]. Genomic prediction is particularly useful for traits for which phenotyping is expensive, difficult or time consuming, since no phenotyping is needed for selection, once a good prediction model based on data of a representative training population is available. This technique has been widely applied in animal selection [83-85], while its practical application in plant breeding is still limited to major crops, such as maize and wheat [82,86,87], in which QTLs for important traits, such as yield, have already been fixed in the elite germplasm [88], or to tree crops, where early selection is very useful and cost-effective [89].

The combination of all the above-mentioned approaches, except GP, led to identification of a multitude of QTLs for many agronomic and quality traits. In this review we aim to collect, compare, integrate and summarize the available literature on flavour-related QTLs in tomato. We selected 16 scientific papers and supplemental data focusing on QTLs for tomato aroma and fruit quality. This not only provides an overview of the known flavour QTLs, but the combined and integrated information also makes it possible to (i) pinpoint potential donors described in literature for specific traits, (ii) highlight important QTL regions by combining information from different populations, and (iii) pinpoint potential candidate genes. This overview aims to be a valuable resource for researchers aiming to elucidate the genetics underlying tomato flavour and for breeders who aim to improve tomato aroma. 


\section{Construction of a Unified QTL Map of Tomato Aroma}

A literature search was performed with the aim of collecting articles reporting QTLs for tomato aroma. In order to compare and integrate QTLs from different studies, the availability of marker information was an essential requirement for inclusion in this review. The identified QTLs have been organized and are available as Supplemental Material (Table S5), reporting the biosynthetic pathway, the QTLs Genomic Regions (QGR), the QTL's original name, the related compound, the chromosome, the correlated markers, their position in $\mathrm{cM}$ and $\mathrm{bp}$, their $p$-value, their LOD score, the SolycID of the gene in which the markers have been found, the percentage of explained variation by the QTL, the effect, the donor parent, the crossing population or association panel used and the reference of the primary resource.

We identified 16 articles reporting QTLs for tomato aroma including marker information (Table 2). In the pre-genomics era only genetic linkage positions (cM) of QTLs could be reported, since a reference genome sequence was not available the. This made it difficult to align QTLs of that period with the more recent studies utilizing modern genomics technologies. To circumvent this, the physical position of genetic markers was retrieved from the tomato genome (https://solgenomics.net/search/markers (accessed on 20 November 2020)) whenever marker sequence information was available, using the SL2.50 genome version.

Table 2. List of the articles reporting QTLs for tomato aroma included in the review. RILs: Recombinant Inbred Lines; BCs: Backcross population; ILs: Introgression Lines; GWAS: Genome-Wide Association Studies; DP: Diversity Panel.

\begin{tabular}{lll}
\hline Author, Year & Population & References \\
\hline Saliba-Colombani et al., 2001 & RILs & {$[90]$} \\
Fulton et al., 2002 & BCs & {$[91]$} \\
Tadmor et al., 2002 & ILs & {$[92]$} \\
Tieman et al., 2006 & ILs & {$[93]$} \\
Mathieu et al., 2009 & ILs & {$[6]$} \\
Kochevenko \& Fernie, 2011 & ILs & {$[94]$} \\
Ruggieri et al., 2014 & GWAS & {$[95]$} \\
Sauvage et al., 2014 & GWAS & {$[74]$} \\
Capel et al., 2015 & RILs & {$[96]$} \\
Zhao et al., 2016 & GWAS & {$[97]$} \\
Baldina et al., 2016 & GWAS & {$[98]$} \\
Bauchet et al., 2017 & GWAS & {$[99]$} \\
Tieman et al., 2017 & GWAS & {$[25]$} \\
Garbowicz et al., 2018 & ILs & {$[100]$} \\
Kimbara et al., 2018 & RILs & {$[101]$} \\
Tikunov et al., 2020 & F2, F6, DP & {$[102]$} \\
\hline
\end{tabular}

Two criteria were used to cluster QTL information from the different studies into QTLs Genomic Regions (QGRs) in a unified physical map (Figure 1): (i) a biochemical relationship between aroma volatiles and their possible precursors, such as similar chemical structure or common biosynthetic pathway and (ii) overlapping of the QTLs. Since most of the studies only reported the most significant marker(s) of an identified QTL, while information on genetic confidence intervals or (average) linkage disequilibrium (LD) decay was lacking, it was virtually impossible to determine the size of QTL regions. For this reason, we standardized the potential positional error across the reported studies by setting an empirically defined window of $\pm 2.5 \mathrm{Mb}$ around each identified QTL. This window was derived from the average inter-study standard deviation of QTL positions of the three most functionally explored tomato aroma loci-floral aroma on chromosome $4[25,90,99,102]$, smoky aroma on chromosome $9[25,90,102]$ and the malodorous locus on chromosome $8[92,93,99]$. The major genetic factors underlying these QTLs were identified and, therefore, the dispersion of QTL positions in these different studies could most likely be attributed 
to non-genetic sources of variation. This window as well as resulting QGRs only serve as means to classify QTLs and indicate the possibility that the individual QTLs they harbor may be affected by one or a few co-localized genetic factors.
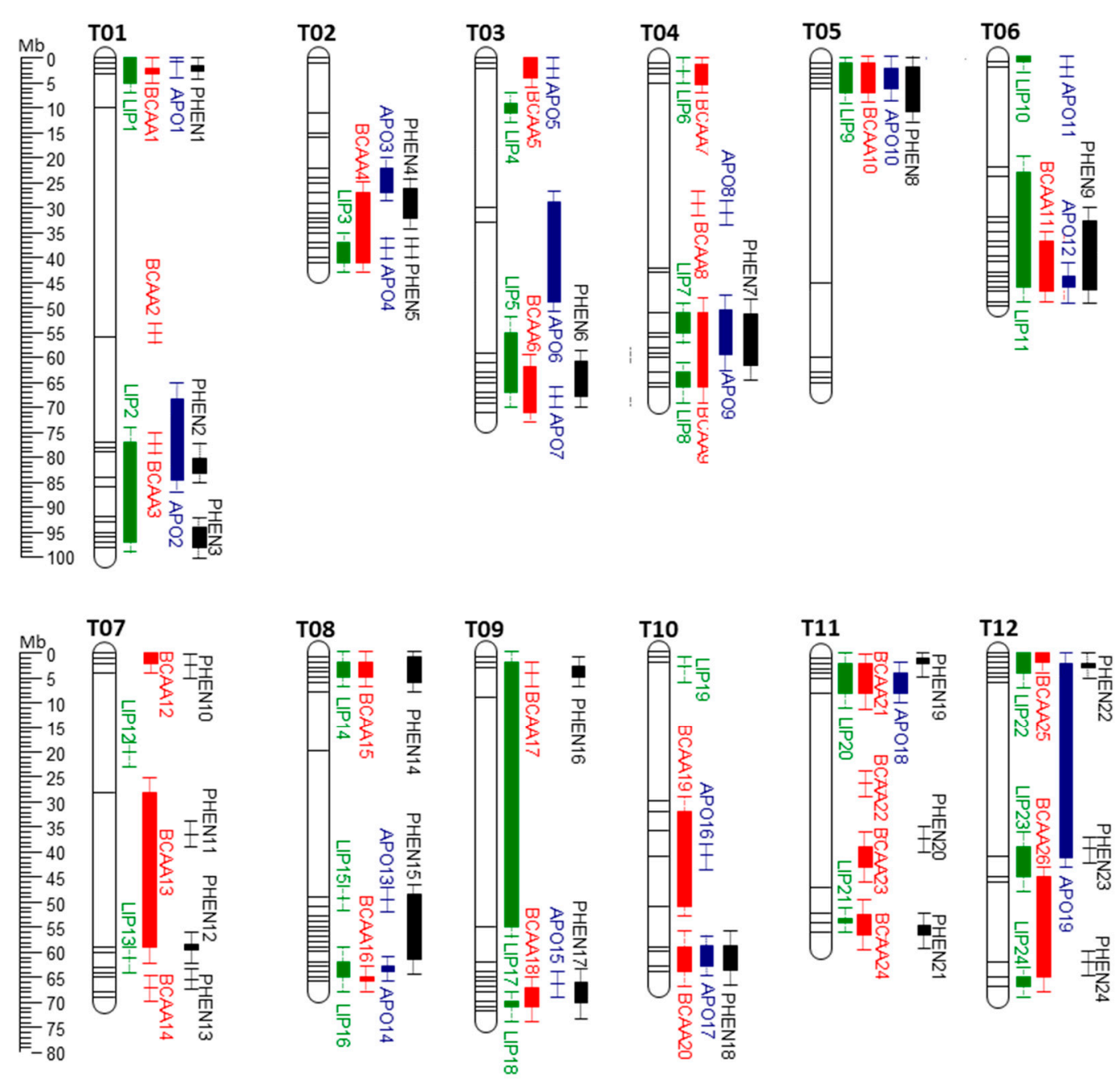

Figure 1. VOCs QGRs chromosome map (T01-T12) obtained from the reported literature. Green: Lipid VOCs QGRs; Red: BCAA VOCs' QGRs; Blue: Apocarotenoid VOCs QGRs; Black: phenolic VOCs QGRs. The estimated confidence interval $( \pm 2.5 \mathrm{Mb})$, has been reported in the figure.

The identified QGRs were mined for the presence of candidate genes based on their annotation (ITAG2.40) and on their expression in tomato fruit, using publicly available dataset and tools [103]. Candidate genes were defined by two criteria: (1) genes belonging to families known from literature to be involved in VOCs biosynthesis and expressed in tomato fruit and (2) genes reported in literature with a demonstrated function in VOCs biosynthesis, irrespective of their expression in tomato fruit. A complete list of the potential candidate genes (with and without expression in the fruit tissues) can be found as Supplemental Material (Tables S1-S4). The genes which have been demonstrated to functionally underlie aroma QTLs in tomato were highlighted in bold.

\section{Fatty Acids Derived Volatiles (FA VOCs)}

The volatile compounds originating from the degradation of linolenic and linoleic acid accumulate during tomato ripening and can also markedly increase their emission upon fruit tissue disruption. They provide a note of freshly cut grass to the aroma bouquet [104]. These compounds are the most abundant volatiles in tomato fruit and are 
mainly represented by the $C_{5}$ volatile 1-penten-3-one, a few $C_{6}$ volatiles, such as 1-hexanol, (Z)-3-hexenal, (E)-2-hexenal and hexanal, the $C_{7}$ volatile $(E)$-2-heptenal and the $\mathrm{C}_{10}$ VOC $(E, E)-2,4$-decadienal $[8,11,16,17]$. Although their high accumulation in ripe fruits may suggest that these compounds are very important determinants of tomato flavour, some studies provide evidence that impact of their quantitative variation on consumer liking may be limited $[8,67]$, likely due to their in general high abundance and low odor thresholds, e.g., for (Z)-3-hexenal these values are $12,000 \mathrm{nLL}^{-1}$ and $0.25 \mathrm{nLL}^{-1}$, respectively [21].

\subsection{Biosynthesis of FA VOCs}

During tomato fruit ripening, free fatty acids, mainly linolenic and linoleic acid, are derived from the catabolism of acylglycerides from disintegrating cellular membranes, by the action of lipases $[87,88]$. Linolenic and linoleic acid can be further catabolized by means of $\beta$-oxidation, $\alpha$-oxidation, or the lipoxygenase pathway [68,105-107]. In tomato fruit the latter is the most important for the production of volatiles, which occurs through two steps: (i) fatty acids are deoxygenated by means of lipoxygenases (LOX), which are classified as 13-LOX and 9-LOX and are leading respectively to 13-hydroperoxides and 9-hydroperoxides [67,108]; (ii) hydroperoxides are catabolized by means of hydroperoxide lyases (HPL), also classified as 13-HPL and 9-HPL, leading to an oxoacid and a volatile aldehyde. Volatile aldehydes can be converted into alcohols by means of alcohol dehydrogenases (ADH; [109-114]). According to the literature ([68]), 13-LOX enzymes are mainly involved in the synthesis of (Z)-3-hexenal from linolenic acid and hexanal from linoleic acid. Among these enzymes, TomloxC has shown significant correlation with the production of hexanal, together with LeHPL, a 13-HPL $[67,68,115]$. Another gene, $A D H 2$, has been reported as positively related to the production of hexanol and (Z)-3-hexenol [116] while ADH1 showed in vitro activity in the conversion of hexanal into hexanol [117]. Figure 2 summarizes the complete biosynthetic pathway of the lipid-derived VOCs, according to the available literature.

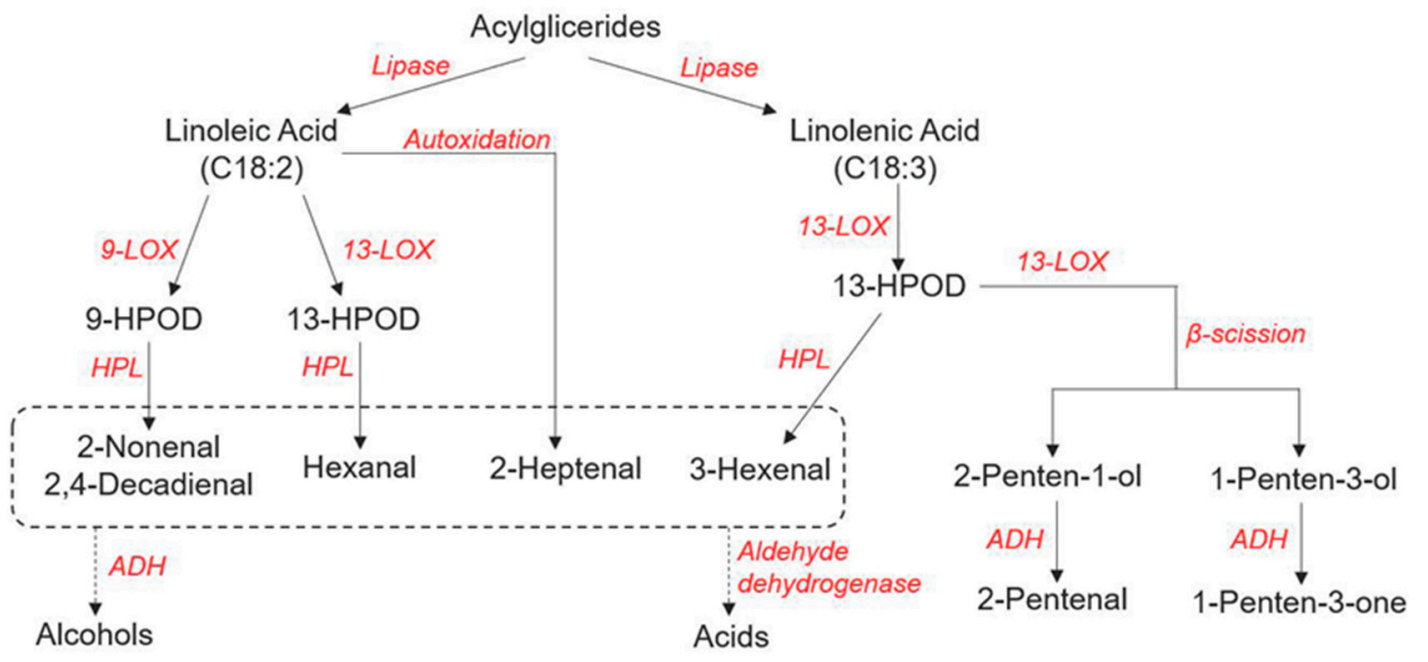

Figure 2. Overview of the lipid VOCs pathway, adapted from [118-120].

\subsection{QTLS for FA VOCS}

Data collection identified a total number of 108 QTLs reported in 8 different studies and correlated with lipid volatiles biosynthesis (Table S1). Comparing these regions (see "Data Acquisition and Classification"), we identified 24 distinct QGRs (Figure 1, Table S1).

\subsection{FA VOCs' Candidate Genes}

The collected data allowed the identification of 112 genes potentially involved in lipid VOCs biosynthesis (Table S1). Among them, 28 genes have been reported to be expressed in 
at least one fruit tissue (Table 3; [103]), or have been functionally characterized for their role in fatty acids metabolism. Eight lipoxygenases (LOXs) were identified as candidate genes expressed in tomato fruit. Among the identified LOXs, three have been reported for their association with lipid VOCs: LoxC (Solyc01g006540) has a major role in the biosynthesis of the most quantitatively prominent C5 and C6 lipid-derived VOCs, LoxF (Solyc01g006560) is involved in the production of fatty acid VOCs derived from 13-hydroperoxides [3,121].

Table 3. List of the genes identified as potentially responsible for the lipid VOCs QTLs reported in literature. Genes that have been functionally characterized are highlighted in bold in the table. The last column reports whether the gene has been reported to be expressed in fruit (Y/N-[103]), for a complete overview of the gene expression see Table S1.

\begin{tabular}{|c|c|c|c|c|c|c|}
\hline Solyc ID & Name & QGR & $\begin{array}{l}\text { Start } \\
(\mathrm{bp})\end{array}$ & Annotation & Reference & $\begin{array}{c}\text { Expressed } \\
(\mathrm{Y} / \mathrm{N})\end{array}$ \\
\hline Solyc01g006540 & $\operatorname{lox} C$ & LIP1 & $1,113,718$ & Lipoxygenase & [68] & $\mathbf{Y}$ \\
\hline Solyc01g006560 & $\operatorname{lox} F$ & LIP1 & $1,128,815$ & Lipoxygenase & [121] & $\mathbf{N}$ \\
\hline Solyc01g099210 & - & LIP1 & $89,509,072$ & Lipoxygenase & & $\mathrm{Y}$ \\
\hline Solyc01g108150 & - & LIP2 & $95,505,678$ & Oxidoreductase zinc-binding dehydrogenase family protein & & $\mathrm{Y}$ \\
\hline Solyc02g090930 & - & LIP2 & $52,398,542$ & Lipase & & $\mathrm{Y}$ \\
\hline Solyc03g093360 & - & LIP3 & $54,632,041$ & Lipoxygenase & & $\mathrm{Y}$ \\
\hline Solyc03g095360 & - & LIP5 & $56,412,064$ & Alcohol dehydrogenase zinc-binding & & $\mathrm{Y}$ \\
\hline Solyc03g111550 & - & LIP5 & $62,149,409$ & GDSL esterase/lipase & & $\mathrm{Y}$ \\
\hline Solyc04g010250 & - & LIP6 & $3,577,656$ & Lipase-like protein & & $\mathrm{Y}$ \\
\hline Solyc04g054980 & - & LIP7 & $53,517,056$ & Lipoxygenase homology domain-containing protein 1 & & $\mathrm{Y}$ \\
\hline Solyc04g054990 & - & LIP7 & $53,522,447$ & Lipoxygenase homology domain-containing protein 1 & & $\mathrm{Y}$ \\
\hline Solyc04g064710 & - & LIP7 & $55,858,388$ & Alcohol dehydrogenase 2 & & $\mathrm{Y}$ \\
\hline Solyc05g005480 & $\begin{array}{l}E O \\
O R\end{array}$ & LIP9 & 352,211 & Oxidoreductase zinc-binding dehydrogenase & & Y \\
\hline Solyc05g009390 & - & LIP9 & $3,544,526$ & Lipase-like protein & & Y \\
\hline Solyc06g059740 & $A D H 2$ & LIP11 & $37,606,747$ & Alcohol dehydrogenase 2 & & $\mathbf{Y}$ \\
\hline Solyc07g045090 & - & LIP13 & $58,206,449$ & Alcohol dehydrogenase zinc-binding domain protein & [116] & $\mathrm{Y}$ \\
\hline Solyc08g014000 & LOXA & LIP14 & $3,516,113$ & Lipoxygenase & & $\mathrm{Y}$ \\
\hline Solyc09g059030 & - & LIP17 & $53,010,842$ & Alcohol dehydrogenase zinc-containing & & $\mathrm{Y}$ \\
\hline Solyc09g059040 & - & LIP17 & $53,050,984$ & Alcohol dehydrogenase zinc-containing & & $\mathrm{Y}$ \\
\hline Solyc09g091050 & - & LIP18 & $70,389,731$ & Lipase & & $\mathrm{Y}$ \\
\hline Solyc11g010960 & - & LIP20 & $4,006,687$ & Alcohol dehydrogenase & & $\mathrm{Y}$ \\
\hline Solyc11g011330 & - & LIP20 & $4,375,432$ & Cinnamyl alcohol dehydrogenase & & $\mathrm{Y}$ \\
\hline Solyc11g065530 & - & LIP21 & $50,971,492$ & Lipase (Fragment) & & $\mathrm{Y}$ \\
\hline Solyc11g071290 & - & LIP21 & $54,819,572$ & Alcohol dehydrogenase & & $\mathrm{Y}$ \\
\hline Solyc12g010950 & - & LIP22 & $3,827,848$ & Alcohol dehydrogenase zinc-containing & & $\mathrm{Y}$ \\
\hline Solyc12g011040 & - & LIP22 & $3,894,074$ & Lipoxygenase & & $\mathrm{Y}$ \\
\hline Solyc12g096760 & - & LIP24 & $65,539,079$ & Alcohol dehydrogenase zinc-containing & & $\mathrm{Y}$ \\
\hline Solyc12g096780 & - & LIP24 & $65,557,520$ & Mitochondrial trans-2-enoyl-CoA reductase & & $\mathrm{Y}$ \\
\hline
\end{tabular}

Eleven alcohol dehydrogenases (ADH) were identified. ADHs are a family of enzymes associated with the interconversion of the aldehyde and alcohol forms of lipid volatiles in tomato and they have been reported to accumulate in the fruit during ripening $[6,116]$. Among them, Solyc06g059740 has been characterized in tomato fruit as ADH2 [116,122,123]. Solyc11g071290 was identified in the LIP21 QGR, a QTL for the earthy/mushroom odor type volatile 1-octen-3-one-which, unlike the major C6 VOCs, has rarely been suggested as an important fresh tomato fruit odorant, has a much lower concentration than C6 VOCs, but has an extremely low odor threshold of $0.005 \mathrm{nLL}^{-1}$ [124]. A structural variation in the promoter of this gene was reported in [26]. The wild allele was present in S. pimpinellifolium and $S$. cerasiforme, but was not found in heirloom tomatoes, suggesting selection against the wild allele during domestication. Although this gene showed a significant expression level in one fruit sample only (S. pimpinellifolium fruit at 4 DPA), we cannot exclude that allelic differences in this gene may be responsible for the 1-octen-3-one QTL identified by GWAS [99].

\section{Branched-Chain Amino Acids Derivatives (BCAA VOCs)}

Branched-chain amino acid (BCAA) derived compounds are highly volatile compounds with a low molecular weight, some of which are considered important in the development of tomato aroma, e.g., 3- and 2-methylbutanal (aldehydic/chocolate/musty odor types), 3- and 2-methylbutanol (roasted/fermented odor types), and 2-isobutyl-thiazole (green/wasabi odor), which is partly derived from BCAA $[10,12,16]$. 


\subsection{Biosynthesis of BCAA VOCs}

Even though the relationship between BCAA VOCs and the tomato aroma is clear, the exact molecular mechanism underlying their quantitative variation in tomato fruit is not fully understood. In general, BCAA VOCs originate from the branched-chain amino acid (BCAA) pathway in many organisms including plants. BCAA biosynthesis has been studied well in plants and it takes place in the chloroplast where leucine and valine are synthesized from pyruvate and isoleucine from threonine via several enzymatic reactions (Figure 3). Catabolism of BCAAs, which occurs in mitochondria is believed to be the source of BCAA VOCs in tomato fruit. It has been suggested that the first step in the catabolic pathway leading to BCAA VOCs is the reversible conversion of branched-chain amino acids (leucine, isoleucine) into their corresponding $\alpha$-ketoacids by means of branchedchain amino acid aminotransferases (BCATs; [125]). The importance of BCATs in the degradation of BCAAs has been demonstrated in Arabidopsis [126]. In tomato different members of the BCAT family have been shown to mediate either synthetic or catabolic reactions of BCAAs [94,127-129]. The products of the reversible BCAT-mediated BCAA deamination- $\alpha$-ketoacids-have been suggested to be the likely precursors for BCAA VOCs [128], which then could be produced through the combined action of various classes of candidate enzymes (Figure 3), such as $\alpha$-ketoacid dehydrogenases, decarboxylases and alcohol/aldehyde dehydrogenases [130].

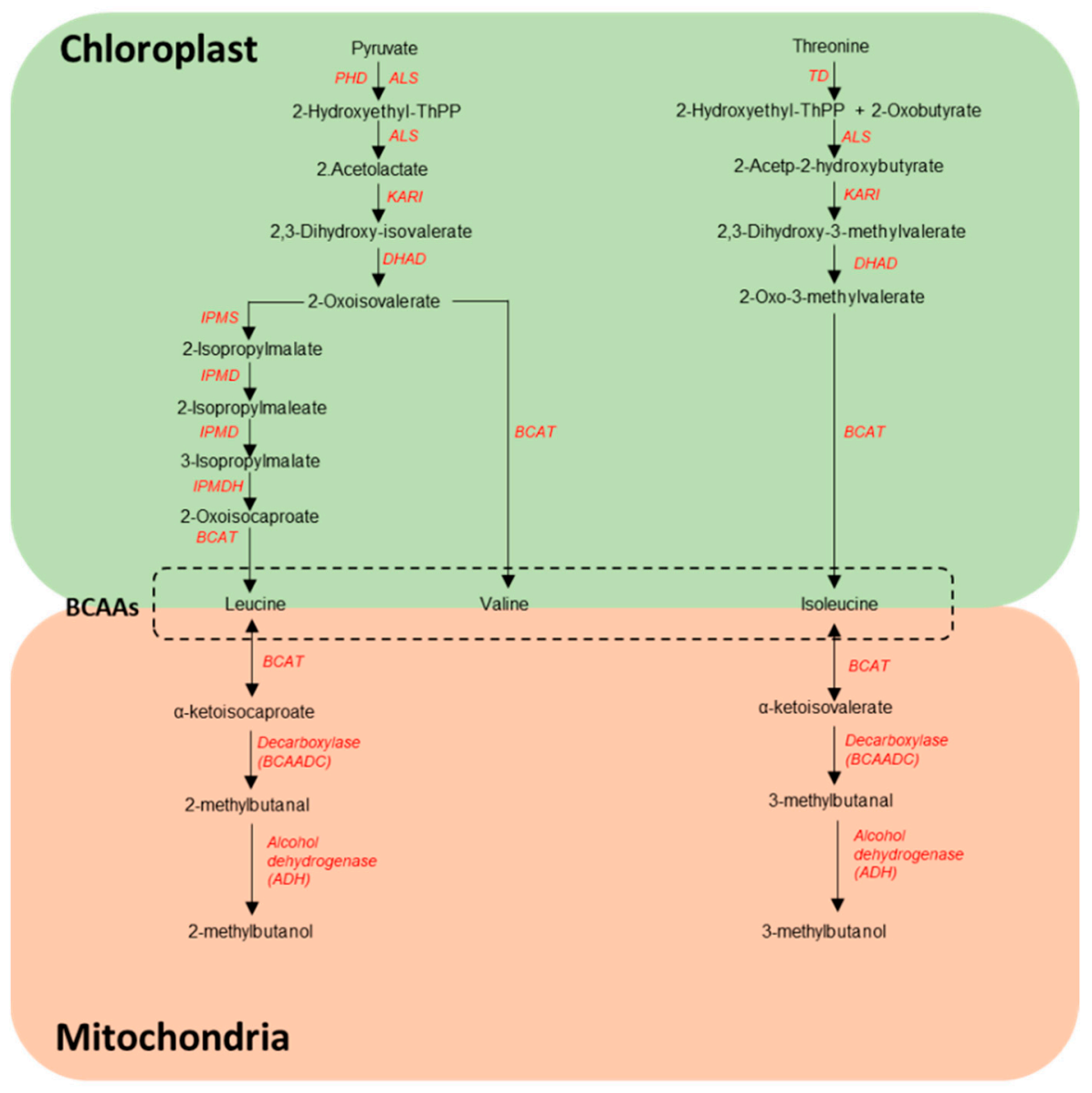

Figure 3. Overview of the proposed BCAA VOCs pathway, adapted from [94,130]. TD: threonine dehydratase; ALS: acetolactate synthase; KARI: ketol-acid reductoisomerase; DHAD: dihydroxy-acid dehydratase; BCAT: branched-chain aminotransferase; IPMS: 2-isopropylmalate synthase; IPMD: 3-isopropylmalate dehydratase; IPMDH: 3-isopropylmalate dehydrogenase; PDH: pyruvate dehydrogenase. 


\subsection{QTLS for BCAA VOCS}

Data collection identified a total number of 129 QTLs reported by seven different authors and correlated with BCAA volatiles biosynthesis (Figure 1; Table S2). These QTLs were classified into 26 distinct QGRs (Table S2).

\subsection{BCAA VOC Candidate Genes}

Table S2 reveals 75 genes that were identified as potentially involved in the BCAA VOCs metabolism, 28 of which have been reported to be expressed in at least one fruit tissue [103]. An overview of the 30 selected candidate genes is shown in Table 4, including genes expressed in fruits plus two functionally characterized genes (BCAT2 and BCAT4; see below).

Among the genes identified as expressed in tomato fruit, ten belong to enzymatic families that have been associated with BCAA biosynthesis: four genes were annotated as pyruvate dehydrogenases (PDH), three as 3-isopropylmalate dehydratases (IPMD), two as ketol-acid reductoisomerase (KARI) and one as 2-isopropylmalate synthase (IPMS). Reverse genetics analysis of Solyc06g060790 (IPMD) revealed that this gene influences the BCAA content in tomato fruit, while a similar analysis failed to support such a conclusion in case of Solyc07g053280 (KARI) [94]. Branched chain amino acid aminotransferases (BCATs) can be involved in the last step of BCAA anabolism and/or in the first step of BCAA catabolism depending on their subcellular localization (chloroplast or mitochondrion, respectively). Six BCAT genes were reported as candidate genes in Table 4, of which five (BCAT1, 2, 3, 4 and 7) have been functionally characterized [112,114]. Although BCAT2, 4 and 7 were located outside the QTL intervals, they were included in this review for completeness. BCAT1 and $B C A T 2$ were shown to be located in mitochondria and involved in the catabolism of BCAAs, while BCAT3 and BCAT4 were shown to be located in chloroplasts and involved in BCAA biosynthesis. In turning and ripe fruits of cv. M82 BCAT1 expression was up to 10-fold higher compared to BCAT2, 3 and 4 . Although BCAT2, 3 and 4 showed low, but detectable expression in fruits, their expression was much higher in leaves (BCAT2 and 3 ) or inflorescence (BCAT4) in this tomato background [127]. According to the RNAseq data present in the TomExpress database [103], these three genes are hardly (BCAT3) or not at all expressed in tomato fruits (BCAT2 and 4). Although its subcellular location is unclear, $B C A T 7$ was proposed to play a role in BCAA degradation [128]. Finally, we identified eleven alcohol dehydrogenases (ADH) expressed in tomato fruit in the BCAA QGRs. These may play a role in BCAA catabolism, although their functional characteristics remain to be demonstrated.

The available tomato pangenome [26] was investigated for the presence of nonreference (non cv. Heinz) promoter regions for the abovementioned genes. Interestingly, a non-reference allele was reported for Solyc04g063350, annotated as 3-methyl-2oxobutanoate dehydrogenase, an enzymatic class that has been described as involved in the BCAA catabolism, which involves the decarboxylation of branch chain amino acids $[94,129,131]$. This gene has recently been named FLORAL4 after both genetic and functional studies revealed that its involvement was not restricted to BCAA catabolism, but this gene also controlled the quantitative variation of floral phenolic-derived VOCs derived from catabolism of the aromatic amino acid phenylalanine (see below; [102]). Among the investigated tomato varieties, the cultivars harboring the "wild" allele showed significantly lower gene expression than the ones presenting the domesticated promoter, suggesting a positive selection for FLORAL4 expression during tomato domestication [26]. 


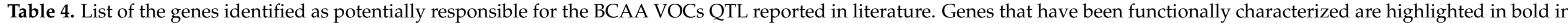
the table. The last column reports whether the gene has been reported to be expressed in fruit (Y/N-[103]); for a complete overview of the gene expression see Table S2.

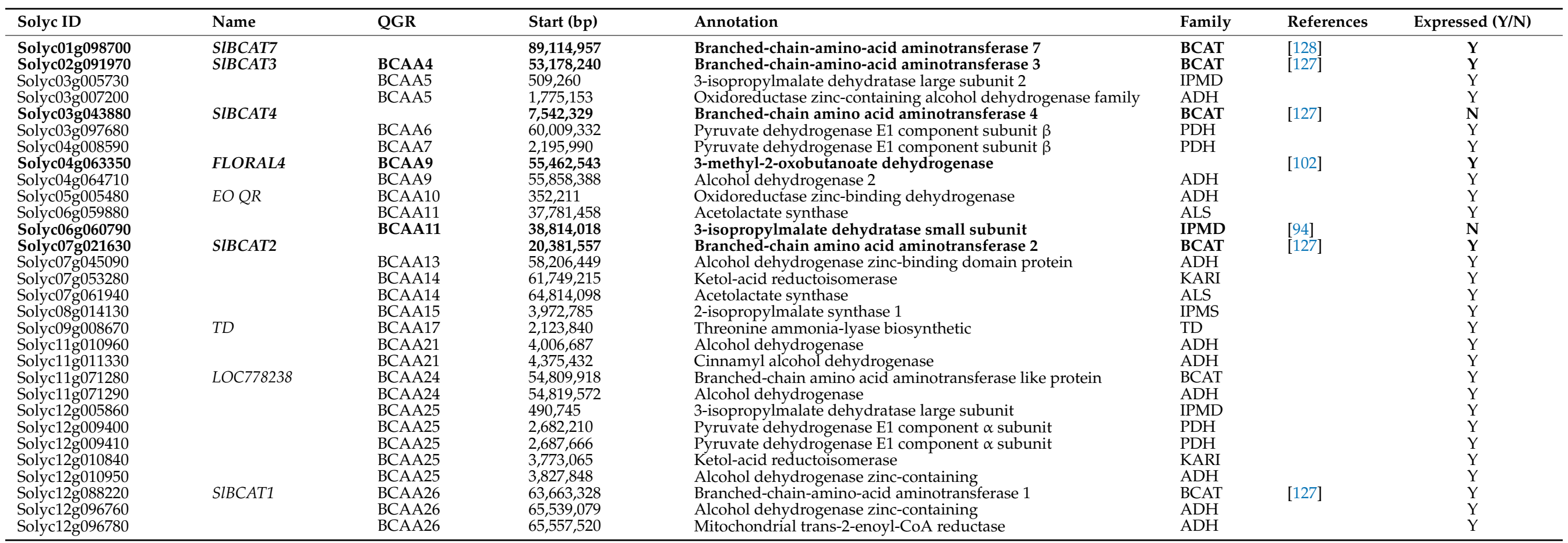




\section{Carotenoid-Derived VOCs}

Carotenoid-derived volatiles (apocarotenoid VOCs) are perceived as "floral" and accumulate in low amounts in tomato fruit [11]. However, due to their low odor thresholds [10], they have been reported to positively correlate with tomato flavour acceptability [15]. There are two groups of carotenoid VOCs that are relevant for tomato aroma [21,132]: (i) cyclic carotenoid volatiles, such as $\beta$-ionone and $\beta$-damascenone (both floral odor type); and (ii) open-chain carotenoid-derived volatiles, such as 6-methyl-5-hepten-2-one, geranial (both citrus odor type) and geranylacetone (floral odor type).

\subsection{Biosynthesis}

Apocarotenoid volatiles are produced in plastids [104] through the cleavage of carotenoids by carotenoid cleavage dioxygenases, like LeCCD1A and LeCCD1B [133], which are particularly expressed during fruit ripening [132]. This family of genes has been reported in other species to act both on cyclic carotenoids (at the $9^{\prime}, 10^{\prime}$ position) and open-chain carotenoids-at the $\left(5^{\prime}, 6^{\prime}\right),\left(7^{\prime}, 8^{\prime}\right)$, or $\left(9^{\prime}, 10^{\prime}\right)$ positions-, leading to the production of the carotenoid VOCs (Figure 4; [133-139]). Although many structural genes in the carotenoid biosynthetic and cleavage pathway are known, the regulation of the carotenoid pathway is still unclear. In this respect it has been proposed that the loss of membrane integrity during the ripening-dependent conversion of chloroplasts into chromoplasts may be a key mechanism in their regulation, as this process may lead to the release of the carotenoids in the cytoplasm, were they will react with cytoplasmatic cleavage enzymes $[15,140]$. The available knowledge of the carotenoid biosynthetic and cleavage pathway and the underlying biosynthetic genes (Figure 4) is very helpful for the identification of candidate genes within QTLs for carotenoid-derived VOCs in tomato fruit.

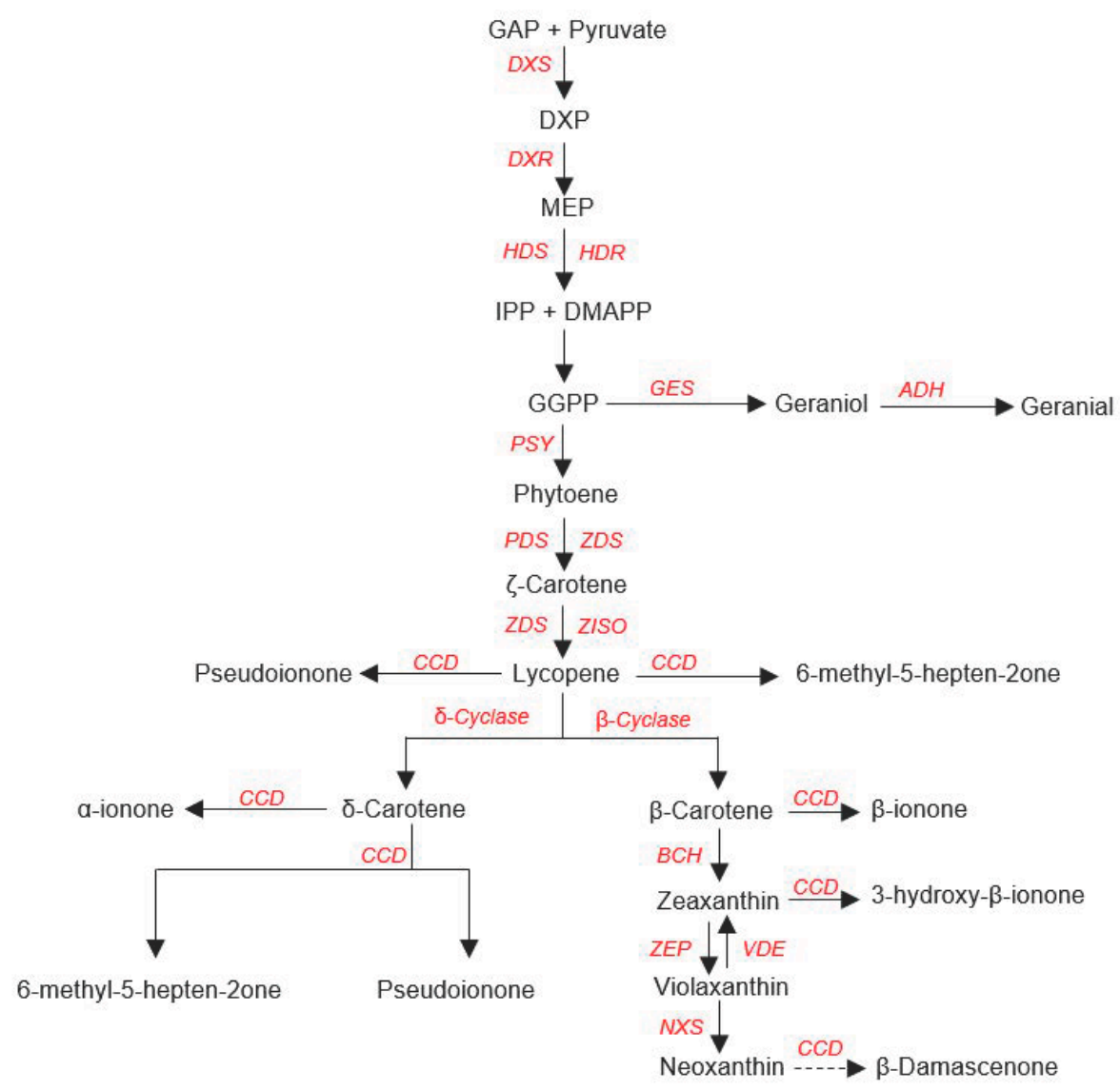

Figure 4. Overview of the carotenoid VOCs pathway, adapted from [135,141,142]. 


\subsection{QTLs for Apocarotenoid VOCs}

Data collection identified a total number of 42 QTLs reported in 8 different articles and correlated with apocarotenoid volatiles biosynthesis (Figure 1; Table S3). Comparing these regions (see "Data Acquisition" paragraph for methodology), we identified 19 distinct QGRs (Table S3).

\subsection{Apocarotenoid VOCs' Candidate Genes}

Twenty-three genes were identified as potentially associated with apocarotenoid VOCs metabolism (Table S3). For nineteen genes there is functional evidence for their involvement in the carotenoid pathway and five of those (Solyc03g007960, Solyc03g031860, Solyc03g123760, Solyc06g036260, Solyc10g081650) have also been shown to be expressed in at least one fruit tissue based on [103]. Solyc06g036260 (Crtz1), Solyc03g114340 (DXR), Solyc03g123760 (PDS), Solyc04g040190 (LCY-B1) are located outside the QTL regions, but were included for completeness (Table 5; [137,143-154]).

Two genes have been annotated as 1-deoxy-D-xylulose 5-phosphate synthases (DXS), reported as first and key regulatory step of the MEP pathway required for the production of carotenoids $[141,143,155]$. Most of the structural genes of the carotenoid pathway are found within the QTL regions, including three phytoene synthases required for the production of phytoene, the first carotenoid of the pathway [144,149,156-160], followed by phytoene desaturase [152] and one carotenoid isomerase [161], required for the production of lycopene, two lycopene cyclases, involved in the production of $\alpha$ - and $\beta$-carotene $[153,154,162,163]$, one carotene hydroxylase to form zeaxanthin $[159,164]$, and finally one zeaxanthin epoxidase, an enzymatic class that converts zeaxanthin, precursor of 3 -hydroxy- $\beta$-ionone, into violaxanthin $[132,135,151,165]$. As mentioned above, lycopene $\beta$-cyclase 1 (Solyc04g040190) was not associated with any of the apocarotenoid QGRs. In total four carotenoid cleavage dioxygenases (CCDs) were present in the QGRs. Two CCD's were annotated as carotenoid cleavage dioxygenase 1A (CCD1A-Solyc01g087250) and $1 \mathrm{~b}$ (CCD1B-Solyc01g087260) and have been shown to be directly involved in carotenoid VOCs accumulation in tomato $[132,138]$, one was annotated as carotenoid cleavage dioxygenase 2 (CCD2-Solyc01g087270), reported to be involved in the formation of carotenoid VOCs in Crocus sativus [137], and one as carotenoid cleavage dioxygenase 7 (CCD7Solyc01g090660), associated with $\beta$-carotene cleavage to carlactone [166]. Two CDDs (CCD4A-Solyc08g075480, CCD4B-Solyc08g075490) have been reported to be associated with tomato fruit color, flavour, and aroma [167-169], but were not comprised in any identified QGR.

Phytoene synthase 2 (PSY2-Solyc02g081330) represents an exception to our candidate gene mining approach. This gene has been annotated at $45 \mathrm{Mb}$ on chr 2 and is located between QGRs APO3-4. Although this gene is not comprised among the regions identified by this review, its activity has been associated with carotenoid production in fruit in other Solanaceae [170]. For this reason, it has been proposed here as potential candidate gene for tomato apocarotenoid VOCs. 
Table 5. List of the genes identified as potentially responsible for the carotenoid VOCs QTL reported in literature. Genes that have been functionally characterized are highlighted in bold in the table. The last column reports whether the gene has been reported to be expressed in fruit (Y/N-[103]); for a complete overview of the gene expression see Table S3.

\begin{tabular}{|c|c|c|c|c|c|c|}
\hline Solyc ID & Name & QGR & Start (bp) & Annotation & References & Expressed $(\mathrm{Y} / \mathrm{N})$ \\
\hline Solyc01g005940 & PSY3 & APO1 & 613,955 & Phytoene synthase 3 & [171] & $\mathbf{N}$ \\
\hline Solyc01g067890 & DXS1 & APO2 & $76,868,469$ & 1-Deoxy-D-xylulose 5-phosphate synthase 1 & {$[145,155]$} & $\mathbf{N}$ \\
\hline Solyc01g087250 & CCD1A & APO2 & $82,184,585$ & Carotenoid cleavage dioxygenase $1 \mathrm{~A}$ & {$[132,138]$} & $\mathbf{N}$ \\
\hline Solyc01g087260 & $C C D 1 B$ & APO2 & $82,196,996$ & Carotenoid cleavage dioxygenase 1B & {$[132,138]$} & $\mathbf{N}$ \\
\hline Solyc01g087270 & $\mathrm{CCD2}$ & APO2 & $82,209,237$ & Carotenoid cleavage dioxygenase 2 & [137] & $\mathbf{N}$ \\
\hline Solyc01g090660 & $C C D 7$ & APO2 & $84,307,951$ & Carotenoid cleavage dioxygenase 7 & [166] & $\mathbf{N}$ \\
\hline Solyc02g081330 & PSY2 & $\mathrm{APO} 3 / 4$ & $45,335,358$ & Phytoene synthase 2 & & $\mathrm{~N}$ \\
\hline Solyc02g090890 & $Z E P$ & APO4 & $52,369,708$ & Zeaxanthin epoxidase, $2 \mathrm{C}$ chloroplastic & [151] & $\mathbf{N}$ \\
\hline Solyc03g007960 & CrtZ-2 & APO5 & $2,447,872$ & $\beta$-Carotene hydroxylase 2 & {$[164]$} & $\mathbf{Y}$ \\
\hline Solyc03g031860 & PSY1 & APO5 & $4,326,134$ & Phytoene synthase 1 & [171] & $\mathbf{Y}$ \\
\hline Solyc03g114340 & DXR & & $64,347,674$ & $\begin{array}{l}\text { 1-Deoxy-D-xylulose-5-phosphate } \\
\text { reductoisomerase }\end{array}$ & {$[143]$} & $\mathbf{N}$ \\
\hline Solyc03g123760 & PDS & & $70,501,011$ & Phytoene desaturase & [152] & $\mathbf{Y}$ \\
\hline Solyc04g040190 & $L C Y-B 1$ & & $11,947,053$ & Lycopene $\beta$-cyclase 1 & [153] & $\mathbf{N}$ \\
\hline Solyc06g036260 & CrtZ-1 & & $25,742,578$ & $\beta$-Carotene hydroxylase 1 & [162] & $\mathbf{Y}$ \\
\hline Solyc06g074240 & $L C Y-B 2$ & APO12 & $45,898,227$ & Lycopene $\beta$-cyclase 2 & [153] & $\mathbf{N}$ \\
\hline Solyc08g075480 & $C C D 4 A$ & & $59,627,153$ & Carotenoid cleavage dioxygenase $4 \mathrm{~A}$ & [167] & $\mathbf{N}$ \\
\hline Solyc08g075490 & $C C D 4 B$ & & $59,643,898$ & Carotenoid cleavage dioxygenase $4 \mathrm{~B}$ & [167] & $\mathbf{N}$ \\
\hline Solyc10g079480 & $L C Y-b$ & APO17 & $61,024,821$ & Lycopene $\beta$-cyclase & [153] & $\mathbf{N}$ \\
\hline Solyc10g081650 & CRTISO & APO17 & $62,682,440$ & Carotenoid isomerase, $2 \mathrm{C}$ chloroplastic & [161] & $\mathbf{Y}$ \\
\hline Solyc11g010850 & DXS2 & APO18 & $3,870,455$ & 1-Deoxy-D-xylulose 5-phosphate synthase 2 & {$[145,155]$} & $\mathbf{N}$ \\
\hline
\end{tabular}

A search for reported wild promoter regions [26] was performed for the abovementioned candidate genes, identifying Solyc03g114340 (DXR-1-deoxy-D-xylulose-5phosphate reductoisomerase) as the only candidate gene showing a wild allele for its promoter region in the available tomato pangenome. This non-reference allele consists of a $645 \mathrm{bp}$ promoter located at $582 \mathrm{bp}$ upstream of DXR, and has been associated with an occurrence frequency of 0.58 in the Solanum pimpinellifolium $\mathrm{L}$. accessions investigated by [26]. On the other hand, its presence in the Solanum lycopersicum var. cerasiforme and S. lycopersicum heirlooms has been reported to be rare, with an occurrence frequency of 0.05 and 0.02 respectively. The cultivars presenting the wild allele showed a significantly higher expression of Solyc03g11434 compared to the ones harboring the common allele, suggesting a selection against a higher expression of DXR during tomato domestication.

\section{Phenylalanine-Derived Volatiles (Phe VOCs)}

Phenolic and phenylpropanoid volatiles originate from the catabolism of phenylalanine. Phenolic VOCs include compounds such as phenylacetaldehyde, 2-phenylethanol, 1-nitro-2-phenylethane and 2-phenylacetonitrile (benzylnitrile; all floral odor type) which have been reported to affect consumer liking of tomato fruit, $[8,12,16,17]$. However, the effect of these phenolic compounds on flavour and consumer preference seems not easy to predict, since some studies show positive while others show negative effects of these compounds on consumer liking $[13,92,172]$. This apparent inconsistency may be caused by differences in the concentrations of these compounds in the tomato materials studied. The main phenylpropanoid VOCs in tomato are guaiacol, methylsalicylate and eugenol. They are associated with a smoky, pharmaceutical aroma and are generally considered as off-flavours.

\subsection{Biosynthesis of Phe VOCs}

Phenolic volatiles $\left(\mathrm{C}_{6}-\mathrm{C}_{2}\right)$ have been reported to have a high impact on tomato aroma [11]. Their biochemical pathway starts with decarboxylation of phenylalanine, leading to the production of phenylethylamine [93]. According to the proposed phenolic volatile biosynthetic pathway in tomato, phenylethylamine is the precursor for the synthesis of the two nitrogen-containing volatiles nitrophenylethane and benzylnitrile, as well as the production of phenylacetaldehyde. Extremely high phenylacetaldehyde levels were found in tomato introgression lines carrying the malodorous locus from S. pennellii on chromosome 8 [92]. The high phenylacetaldehyde production in this line was associated with the expression of AADC1A, AADC1B, and AADC2 located in the malodorous QTL 
region $[93,173,174]$. Transgenic approaches revealed that this family of genes was capable of decarboxylating phenylalanine, leading to phenylethylamine, the direct precursor of phenylacetaldehyde. The subsequent deamination of phenethylamine to produce phenylacetaldehyde has been reported to be related to an amine oxidase. Finally, 2-phenyethanol is produced from phenylacetaldehyde by means of two reductases, PAR1 and PAR2 [175177]. These enzymes are not only reducing phenylacetaldehyde, but they are also able to catalyze the reduction of benzaldehyde and cinnamaldehyde to their respective alcohols as well [175]. More recently, FLORAL4 (Solyc04g063350-3-methyl-2-oxobutanoate dehydrogenase- has been fine mapped in a diversity panel of cultivated contemporary tomato varieties and tomato RIL populations, and associated with the floral phenolic volatiles accumulation in tomato fruit [102]. Based on the protein sequence FLORAL4 belongs to the mitochondrial 2-oxoisovalerate dehydrogenase/decarboxylase enzyme family which is involved in the catabolism of BCAAs and constitutes the E1 subunit of the BCKDC complex, catalyzing the decarboxylation of the BCAA deamination products in plants [131]. A complete knock-out of the FLORAL4 gene by CRISPR-Cas9-mediated gene editing in tomato plants led to a major depletion of the phenylalanine-derived volatiles as well as a notable depletion of BCAA VOCs. This suggests involvement of FLORAL4 in both BCAA and PHE VOC metabolism, possibly via decarboxylation of the corresponding amino or keto acids.

As mentioned above, phenylpropanoid volatiles $\left(\mathrm{C}_{6}-\mathrm{C}_{3}\right)$ are the second group of phenylalanine derived VOCs. Although their biosynthesis in tomato has not been fully characterized, results from other species suggest that phenylpropanoid volatiles are derived from intermediates of the lignin pathway [178-181]. For example, eugenol has been reported in other species to be produced from coniferyl acetate by means of a eugenol synthase [182]. The mechanisms of methyl salicylate and guaiacol biosynthesis have been investigated in tomato [11]. Methyl salicylate can be produced from salicylic acid by means of SISAMT1, an O-methyltransferase [183], while guaiacol may be produced from catechol, by means of the catechol-O-methyltransferase CTOMT1 [184]. Although CTOMT1 could not be connected to any of the QTL regions found, it has been included for completeness. Furthermore, the conjugation of these three compounds after their biosynthesis has been reported to be linked to the activity of two classes of enzymes: glycosyltransferases and glycosyl hydrolases. Among these classes of enzymes, NSGT1 was shown to prevent the wound-induced release of the smoky aroma associated with phenylpropanoid VOCs in ripening tomato fruit [185]. Figure 5 summarizes the metabolic reactions described above.

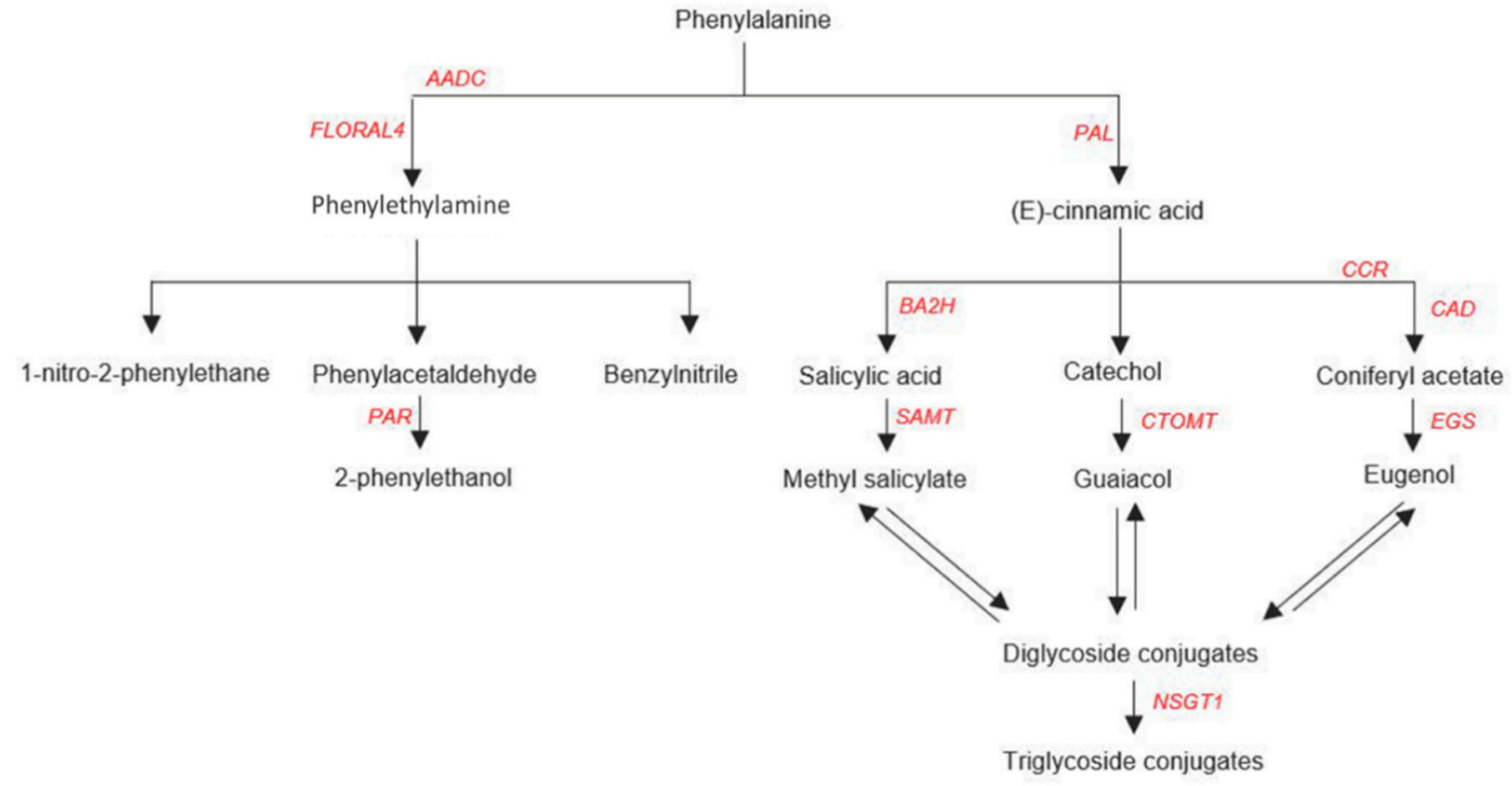

Figure 5. Overview of the phenolic and phenylpropanoid VOCs pathways, adapted from [11]. 


\subsection{QTLs for Phe VOCS}

Data collection identified a total number of 81 QTLs reported by eight different authors and correlated with phenylalanine-derived volatiles biosynthesis (Figure 2; Table S4). Comparing these regions (see "Data Acquisition" paragraph for methodology), we identified 24 distinct QGRs (Table S3).

\subsection{Phe VOCs' Candidate Genes}

Seventy-five genes were identified as potentially associated with phenylalanine derived VOCs, including all candidate genes present in the QGRs plus the above-mentioned CTOMT1 (Solyc10g005060-Table S4). Among them, twenty-one have been reported to be expressed in at least one fruit tissue or were characterized for their role in VOCs metabolism (Table 6 and Table S4; [103]). In addition, the above-mentioned NSGT1, present in QGR PHEN17, was also included in Table 6. NSGT1 expression in tomato fruit was reported by [185], but this gene has not been predicted by the tomato genome and its genomic organization has only recently been resolved [65], and hence gene expression data for this gene could not be retrieved from the TomExpress database.

Table 6. List of the genes identified as potentially responsible for the phenylalanine-derived VOCs QTL reported in literature. Genes that have been functionally characterized are highlighted in bold in the table. The last column reports whether the gene has been reported to be expressed in fruit ( $\mathrm{Y} / \mathrm{N}-[103])$; for a complete overview of the gene expression see Table S4.

\begin{tabular}{|c|c|c|c|c|c|c|}
\hline Solyc ID & Name & QGR & Start (bp) & Annotation & References & Expressed $(\mathrm{Y} / \mathrm{N})$ \\
\hline Solyc01g107910 & & PHEN3 & $95,296,421$ & Caffeoyl CoA 3-O-methyltransferase & & $\mathrm{Y}$ \\
\hline Solyc02g093270 & & PHEN5 & $54,178,272$ & Caffeoyl CoA O-methyltransferase & & $\mathrm{Y}$ \\
\hline Solyc03g097700 & & PHEN6 & $60,029,697$ & O-methyltransferase & & $\mathrm{Y}$ \\
\hline Solyc03g111830 & & PHEN6 & $62,444,512$ & O-methyltransferase & & $\mathrm{Y}$ \\
\hline Solyc04g063350 & FLORAL4 & PHEN7 & $55,462,543$ & 3-methyl-2-oxobutanoate dehydrogenase & [102] & $\mathbf{Y}$ \\
\hline Solyc04g071140 & & PHEN7 & $58,070,304$ & Decarboxylase family protein & & Y \\
\hline Solyc05g013440 & & PHEN8 & $6,501,962$ & Primary amine oxidase & & Y \\
\hline Solyc06g059840 & LOC778303 & PHEN9 & $37,729,682$ & 3-methyl-2-oxobutanoate dehydrogenase & & $\mathrm{Y}$ \\
\hline Solyc08g006740 & $A A D C 2$ & PHEN14 & $1,295,712$ & Decarboxylase family protein & [175] & $\mathbf{N}$ \\
\hline Solyc08g066240 & & PHEN15 & $54,722,572$ & Decarboxylase family protein & & $\mathrm{Y}$ \\
\hline Solyc08g066250 & $H d c$ & PHEN15 & $54,745,923$ & Decarboxylase family protein & & $\mathbf{Y}$ \\
\hline Solyc08g068600 & & PHEN15 & $57,730,921$ & Decarboxylase family protein & & Y \\
\hline Solyc08g068610 & $A A D C 1 B$ & PHEN15 & $57,740,004$ & Decarboxylase family protein & {$[175]$} & $\mathbf{Y}$ \\
\hline Solyc08g068680 & $A A D C 1 A$ & PHEN15 & $57,812,621$ & Decarboxylase family protein & {$[175]$} & $\mathbf{N}$ \\
\hline Solyc08g079430 & & PHEN15 & $62,954,528$ & Primary amine oxidase & & Y \\
\hline Solyc09g007890 & & PHEN16 & $1,413,536$ & Phenylalanine ammonia-lyase & & Y \\
\hline Solyc09g007900 & & PHEN16 & $1,419,041$ & Phenylalanine ammonia-lyase & & $\mathrm{Y}$ \\
\hline Solyc09g007910 & & PHEN16 & $1,429,132$ & Phenylalanine ammonia-lyase & & Y \\
\hline Solyc09g007920 & & PHEN16 & $1,435,451$ & Phenylalanine ammonia-lyase & & Y \\
\hline \multirow[t]{2}{*}{ Solyc09g091550 } & SAMT1 & PHEN17 & $70,802,564$ & Salicylate methyltransferase 1 & [183] & $\mathbf{N}$ \\
\hline & NSGT1 & PHEN17 & $64,653,692$ & Glycosyltransferase & [185] & Y \\
\hline Solyc10g005060 & СТОМТ1 & & 53,330 & Catechol-O-methyltransferase 1 & [184] & $\mathbf{Y}$ \\
\hline Solyc10g085830 & & PHEN18 & $64,899,145$ & O-methyltransferase 1 & & Y \\
\hline Solyc10g086180 & & PHEN18 & $65,098,335$ & Phenylalanine ammonia-lyase & & $\mathrm{Y}$ \\
\hline Solyc12g013690 & SlFMO1 & PHEN22 & $4,532,510$ & Monooxygenase FAD-binding protein & [175] & $\mathbf{Y}$ \\
\hline
\end{tabular}

Among the genes identified as expressed in tomato fruit, one was annotated as 3-methyl-2-oxobutanoate dehydrogenase (Solyc04g063350), the above-mentioned FLORAL4 gene and was demonstrated to be the causal gene for the variation in phenolic VOCs in the PHEN7 QGR on chromosome 4.

One gene (SlFMO1-Solyc12g013690) was annotated as flavin-dependent monooxygenases, a class of enzymes that was shown to catalyze the hydroxylation of aromatic compounds in prokaryotes and plants [174-176]. This gene was suggested to play a role in the synthesis of nitrogenous phenolic volatiles, like 2-phenylacetonitrile and 1-nitro-2phenylethane in tomato [186], although this needs experimental confirmation. Furthermore, we identified one primary amine oxidase (Solyc08g079430) that may potentially be involved in the production of 2-phenylacetaldehyde from phenethylamine [93].

We identified five phenylalanine ammonia-lyase (Solyc09g007890, Solyc09g007900, Solyc09g007910, Solyc09g007920, and Solyc10g086180) genes expressed in tomato fruit. These enzymes have been reported to be responsible for the first key step in phenylpropanoid metabolism, catalyzing the conversion of 1-phenylalanine into trans-cinnamate [187]. 
Finally, six decarboxylase genes were reported to be expressed in tomato fruit during ripening [103,188]. Among them, Solyc08g066250 has been reported as SIHDC11 and has been associated with fruit-ripening in tomato [189]. Moreover, LeAADC1A (Solyc08g068680), together with LeAADC1B (Solyc08068610) and LeAADC2 (Solyc08g006740), have been related with the conversion of phenylalanine to phenylethylamine in a S. lycopersicum var. M82 $\times$ S. pennellii tomato IL population [93].

The tomato pangenome [26] was investigated for potential non-reference alleles in the promoter region of the identified candidate genes. A presence-absence variant was detected in the promoter of FLORAL4 (Solyc04g063350). This variant has an occurrence frequency of 0.74 in cultivated heirloom tomato and 0.64 in S. lycopersicum var. cerasiforme, while it occurs at a frequency of 0.02 only in S. pimpinellifolium WL. Gene expression analyses pinpointed a significant difference $\left(p\right.$-value: $\left.5.48 \times 10^{-6}\right)$ between accessions harboring the domesticated versus the wild allele, suggesting that the domesticated allele of FLORAL4 has a lower expression compared to the wild allele.

\section{Concluding Remarks}

In the last decades, a vast array of scientific studies has investigated the genetic components of tomato aroma in modern tomato cultivars and their relatives. However, the methodological differences between different studies, such as the source materials, the type of mapping population, the number of markers, the reference map used, the influence of environmental factors on trait performance and analytical variation in determination of the aroma phenotype, make it difficult for breeders and researchers to efficiently use the available data in their research. This review summarized the state of the art on the understanding of tomato aroma genetics and provides a tool that can be used by breeders and researchers to collect additional evidence for the robustness of their QTL data. The identified QGRs, especially when defined by the overlapping of QTLs from different sources, represent the regions that most likely contain genetic elements that regulate tomato aroma. The QGRs differ from each other by two major parameters-the size and the number of studies contributing to it. The smaller the size of a resulting QGR and the higher the number of studies referring to it suggests a high robustness of such a QGR in a breeding program. Some of the QGRs, however, appeared to be quite large. This most likely indicates the presence of multiple genetic factors controlling the levels of (related) aromatic compounds in such a region, although we cannot exclude the possibility that, in some cases, a large QGR is caused by inaccurate prediction of a QTL due to experimental and/or methodological differences, as mentioned above. For a breeder such large QGRs could indicate a need for further inspection and dissection of the respective QGR in selected donor material, using high-resolution (fine) mapping approaches.

There are various potential applications of these data in practical breeding and breeding research:

(i) The QTL information presented in this review can be directly used to support markerassisted breeding programs aimed at introgressing large-effect aroma QTLs into elite germplasm, for example using the donors indicated in Table S5.

(ii) The current development of pangenome projects paves the way for a new step in tomato breeding research. Advances in computational genomics and long-read sequencing allow an easier and more comprehensive investigation of the genetic variation in tomato collections worldwide. This makes it possible to identify genetic elements that are missing in the reference genome and to discover and use novel markers - such as Structural Variants (SVs) and Present Absent Variants (PAVs) [190]. Thanks to the ongoing reduction in sequencing costs, large sets of genotypes can nowadays be re-sequenced, allowing the application of SV markers in GWAS projects [191, 192]. Furthermore, SV identification in large sets of genotypes can lead to downstream breeding approaches. For example, SV-based linkage mapping can be applied by genotyping mapping populations using SV markers that showed polymorphism in the parental lines [193]. Furthermore, SV studies may help to get more insight in 
the mechanisms leading to a certain phenotype [26,65,194,195], pinpointing the best donors for a certain allele cross. By providing a comprehensive set of candidate genes for tomato aroma, our review may guide researchers and breeders in the selection of the most interesting genes that can be investigated for structural variation.

(iii) The data in this review can be used to support the identification and use of the key genes underlying these QTLs. In combination with available (pan)genomic and transcriptomic information candidate genes present in the QTL regions can be selected and tested for their effects in vivo using either stable transgenic approaches such as CRISPR-CAS9 mediated gene editing or quicker transient overexpression or silencing in tomato fruit. This may not only lead to the identification of the causal genes controlling a trait, but also to the detection of the causal genetic variants underlying trait variation. Such variants, also called functional markers, are the best possible molecular markers for MAS, since they are functionally linked to the trait rather than genetically linked and their use as marker does not need validation in other populations, which is always required with genetically-linked markers [196].

(iv) The information on large effect aroma QTLs provided in this review can alo be used to improve the performance of genomic prediction models, since both geneticallylinked markers and in particular functional markers have been shown to significantly improve the prediction power of GP models compared to the use of random neutral markers [197].

Last but not least we hope that this review may facilitate the development of more tasty tomatoes.

Supplementary Materials: The following are available online at https:/ /www.mdpi.com/2073-4 425/12/2/226/s1, Figures S1-S4: Gene expression (Euclidean heatmap) of the candidate genes identified in this review; Tables S1-S4: QGRs, Candidate Genes and Candidate Genes expressed in tomato fruit for the four classes of VOCs; Table S5: QTLs reported in literature (biosynthetic pathway, QGR, the QTL's original name, related compound, chromosome, correlated markers, their position in cM and bp, their $p$-value, their LOD score, the SolycID of the gene in which the markers have been found, the percentage of explained variation by the QTL, the effect, donor parent, the crossing population or association panel used, and the reference of the primary resource).

Author Contributions: Conceptualization, M.M., A.G.B., Y.T. and E.P.; methodology, M.M., E.P., Y.T. and A.G.B.; resources, M.M.; data curation, M.M. and E.P.; writing-original draft preparation, M.M. and E.P.; writing-review and editing, E.P., Y.T. and A.G.B.; supervision, A.G.B. All authors have read and agreed to the published version of the manuscript.

Funding: This work was partially funded by the European Union's Horizon 2020 Research and Innovation Programme under the Grant Agreement number 677379 (G2P-SOL project: 'linking genetic resources, genomes and phenotypes of solanaceous crops').

Institutional Review Board Statement: Not applicable.

Informed Consent Statement: Not applicable.

Data Availability Statement: Data available in a publicly accessible repository.

Conflicts of Interest: The authors declare no conflict of interest.

\section{References}

1. Peralta, I.; Knapp, S.; Spooner, D.M. New species of wild tomatoes (Solanum section lycopersicon: Solanaceae) from Northern Peru. Syst. Bot. 2005, 30, 424-434. [CrossRef]

2. Schouten, H.J.; Tikunov, Y.; Verkerke, W.; Finkers, R.; Bovy, A.; Bai, Y.; Visser, R.G. Breeding has increased the diversity of cultivated tomato in The Netherlands. Front. Plant Sci. 2019, 10, 1606. [CrossRef] [PubMed]

3. Víquez-Zamora, M.; Vosman, B.; Van De Geest, H.; Bovy, A.; Visser, R.G.F.; Finkers, R.; Van Heusden, A.W. Tomato breeding in the genomics era: Insights from a SNP array. BMC Genom. 2013, 14, 1-13. [CrossRef] [PubMed]

4. Lanfermeijer, F.C.; Dijkhuis, J.; Sturre, M.J.; De Haan, P.; Hille, J. Cloning and characterization of the durable tomato mosaic virus resistance gene Tm-22 from Lycopersicon esculentum. Plant Mol. Biol. 2003, 52, 1039-1051. [CrossRef] [PubMed] 
5. Lin, T.; Zhu, G.; Zhang, J.; Xu, X.; Yu, Q.; Zheng, Z.; Zhang, Z.; Lun, Y.; Li, S.; Wang, X.; et al. Genomic analyses provide insights into the history of tomato breeding. Nat. Genet. 2014, 46, 1220-1226. [CrossRef] [PubMed]

6. Mathieu, S.; Cin, V.D.; Fei, Z.; Li, H.; Bliss, P.; Taylor, M.G.; Klee, H.J.; Tieman, D.M. Flavour compounds in tomato fruits: Identification of loci and potential pathways affecting volatile composition. J. Exp. Bot. 2008, 60, 325-337. [CrossRef]

7. Petro-Turza, M. Flavor of tomato and tomato products. Food Rev. Int. 1986, 2, 309-351. [CrossRef]

8. Tieman, D.; Bliss, P.; McIntyre, L.M.; Blandon-Ubeda, A.; Bies, D.; Odabasi, A.Z.; Rodríguez, G.R.; Van Der Knaap, E.; Taylor, M.G.; Goulet, C.; et al. The chemical interactions underlying tomato flavor preferences. Curr. Biol. 2012, 22, 1035-1039. [CrossRef]

9. Dudareva, N.; Klempien, A.; Muhlemann, J.K.; Kaplan, I. Biosynthesis, function and metabolic engineering of Plant volatile organic compounds. New Phytol. 2013, 198, 16-32. [CrossRef]

10. Buttery, R.G.; Teranishi, R.; Flath, R.A.; Ling, L.C. Fresh Tomato Volatiles: Composition and Sensory Studies. In Flavour Chemistry; Teranishi, R., Buttery, R.G., Shahidi, F., Eds.; American Chemical Society: Washington, DC, USA, 1989; Volume 388, pp. 213-222.

11. Rambla, J.L.; Tikunov, Y.M.; Monforte, A.J.; Bovy, A.G.; Granell, A. The expanded tomato fruit volatile landscape. J. Exp. Bot. 2013, 65, 4613-4623. [CrossRef]

12. Tandon, K.; Baldwin, E.A.; Scott, J.; Shewfelt, R. Linking sensory descriptors to volatile and nonvolatile components of fresh tomato flavor. J. Food Sci. 2003, 68, 2366-2371. [CrossRef]

13. Baldwin, E.A.; Goodner, K.; Plotto, A. Interaction of volatiles, sugars, and acids on perception of tomato aroma and flavor descriptors. J. Food Sci. 2008, 73, S294-S307. [CrossRef] [PubMed]

14. Baldwin, E.A.; Goodner, K.L.; Plotto, A.; Pritchett, K.; Einstein, M.A. Effect of volatiles and their concentration on perception of tomato descriptors. J. Food Sci. 2004, 69, S310-S318. [CrossRef]

15. Vogel, J.T.; Tieman, D.M.; Sims, C.A.; Odabasi, A.Z.; Clark, D.G.; Klee, H.J. Carotenoid content impacts flavor acceptability in tomato (Solanum lycopersicum). J. Sci. Food Agric. 2010, 90, 2233-2240. [CrossRef]

16. Abegaz, E.; Tandon, K.; Scott, J.; Baldwin, E.; Shewfelt, R. Partitioning taste from aromatic flavor notes of fresh tomato (Lycopersicon esculentum, Mill) to develop predictive models as a function of volatile and nonvolatile components. Postharvest Biol. Technol. 2004, 34, 227-235. [CrossRef]

17. Piombino, P.; Sinesio, F.; Moneta, E.; Cammareri, M.; Genovese, A.; Lisanti, M.T.; Mogno, M.R.; Peparaio, M.; Termolino, P.; Moio, L.; et al. Investigating physicochemical, volatile and sensory parameters playing a positive or a negative role on tomato liking. Food Res. Int. 2013, 50, 409-419. [CrossRef]

18. The Good Scents Company-Flavour, Fragrance, Food and Cosmetics Ingredients Information. Available online: http://www. thegoodscentscompany.com/ (accessed on 26 November 2020).

19. Buttery, R.G.; Teranishi, R.; Ling, L.C. Fresh tomato aroma volatiles: A quantitative study. J. Agric. Food Chem. 1987, 35, 540-544. [CrossRef]

20. Buttery, R.G.; Teranishi, R.; Ling, L.C.; Flath, R.A.; Stern, D.J. Quantitative studies on origins of fresh tomato aroma volatiles. J. Agric. Food Chem. 1988, 36, 1247-1250. [CrossRef]

21. Baldwin, E.A.; Scott, J.W.; Shewmaker, C.K.; Schuch, W. Flavor trivia and tomato aroma: Biochemistry and possible mechanisms for control of important aroma components. HortScience 2000, 35, 1013-1022. [CrossRef]

22. Tandon, K.; Baldwin, E.; Shewfelt, R. Aroma perception of individual volatile compounds in fresh tomatoes (Lycopersicon esculentum, Mill.) as affected by the medium of evaluation. Postharvest Biol. Technol. 2000, 20, 261-268. [CrossRef]

23. Tandon, K.S.; Baldwin, E.A.; Goodner, K.L.; JordÃ $¡$ n, M. Characterization of fresh tomato aroma volatiles using GC-Olfatometry. In Proceedings of the Annual Meeting of the Florida State Horticultural Society, Stuart, FL, USA, 10-12 June 2001.

24. Selli, S.; Kelebek, H.; Ayseli, M.T.; Tokbas, H. Characterization of the most aroma-active compounds in cherry tomato by application of the aroma extract dilution analysis. Food Chem. 2014, 165, 540-546. [CrossRef] [PubMed]

25. Tieman, D.; Zhu, G.; Resende, M.F.; Lin, T.; Nguyen, C.; Bies, D.; Rambla, J.L.; Beltran, K.S.O.; Taylor, M.; Zhang, B.; et al. A chemical genetic roadmap to improved tomato flavor. Science 2017, 355, 391-394. [CrossRef]

26. Gao, L.; Gonda, I.; Sun, H.; Ma, Q.; Bao, K.; Tieman, D.M.; Burzynski-Chang, E.A.; Fish, T.L.; Stromberg, K.A.; Sacks, G.L.; et al. The tomato pan-genome uncovers new genes and a rare allele regulating fruit flavor. Nat. Genet. 2019, 51, 1044-1051. [CrossRef]

27. Gur, A.; Semel, Y.; Osorio, S.; Friedmann, M.; Seekh, S.; Ghareeb, B.; Mohammad, A.; Pleban, T.; Gera, G.; Fernie, A.R.; et al. Yield quantitative trait loci from wild tomato are predominately expressed by the shoot. Theor. Appl. Genet. 2010, 122, 405-420. [CrossRef]

28. Liu, Z.; Alseekh, S.; Brotman, Y.; Zheng, Y.; Fei, Z.; Tieman, D.M.; Giovannoni, J.J.; Fernie, A.R.; Klee, H.J. Identification of a Solanum pennellii chromosome 4 fruit flavor and nutritional quality-associated metabolite QTL. Front. Plant Sci. 2016, 7, 1671. [CrossRef]

29. Eshed, Y.; Zamir, D. An introgression line population of lycopersicon pennellii in the cultivated tomato enables the identi-fication and fine mapping of yield-associated QTL. Genetics 1995, 141, 1147-1162. [CrossRef]

30. Fridman, E.; Carrari, F.; Liu, Y.-S.; Fernie, A.R.; Zamir, D. Zooming in on a quantitative trait for tomato yield using interspecific introgressions. Science 2004, 305, 1786-1789. [CrossRef] [PubMed]

31. Canady, M.A.; Meglic, V.; Chetelat, R.T. A library of Solanum lycopersicoides introgression lines in cultivated tomato. Genome 2005, 48, 685-697. [CrossRef] [PubMed] 
32. Barrantes, W.; López-Casado, G.; García-Martínez, S.; Alonso, A.; Rubio, F.; Ruiz, J.J.; Fernández-Muñoz, R.; Granell, A.; Monforte, A. Exploring new alleles involved in tomato fruit quality in an introgression line library of Solanum pimpinellifolium. Front. Plant Sci. 2016, 7, 1172. [CrossRef]

33. Rambla, J.L.; Medina, A.; Fernández-Del-Carmen, A.; Barrantes, W.; Grandillo, S.; Cammareri, M.; López-Casado, G.; Rodrigo, G.; Alonso, A.; García-Martínez, S.; et al. Identification, introgression, and validation of fruit volatile QTLs from a red-fruited wild tomato species. J. Exp. Bot. 2016, 68, 429-442. [CrossRef]

34. Blanca, J.; Montero-Pau, J.; Sauvage, C.; Bauchet, G.; Illa-Berenguer, E.; Díez, M.J.; Francis, D.M.; Causse, M.; Van Der Knaap, E.; Canizares, J. Genomic variation in tomato, from wild ancestors to contemporary breeding accessions. BMC Genom. 2015, 16, 257. [CrossRef]

35. The Tomato Genome Consortium. The tomato genome sequence provides insights into fleshy fruit evolution. Nature 2012, 485 , 635-641. [CrossRef]

36. Ozminkowski, R.; Ozminkowski, R. Pedigree of variety heinz 1706. Rep. Tomato Genet. Coop. 2004, 54, 26.

37. Hamilton, J.P.; Sim, S.-C.; Stoffel, K.; Van Deynze, A.; Buell, C.R.; Francis, D.M. Single nucleotide polymorphism discovery in cultivated tomato via sequencing by synthesis. Plant Genome 2012, 5, 17-29. [CrossRef]

38. Sim, S.-C.; Durstewitz, G.; Plieske, J.; Wieseke, R.; Ganal, M.W.; Van Deynze, A.; Hamilton, J.P.; Buell, C.R.; Causse, M.; Wijeratne, S.; et al. Development of a large SNP genotyping array and generation of high-density genetic maps in tomato. PLoS ONE 2012, 7, e40563. [CrossRef] [PubMed]

39. Elshire, R.J.; Glaubitz, J.C.; Sun, Q.; Poland, J.A.; Kawamoto, K.; Buckler, E.S.; Mitchell, S.E. A robust, simple genotyping-bysequencing (GBS) approach for high diversity species. PLoS ONE 2011, 6, e19379. [CrossRef]

40. Celik, I.; Gurbuz, N.; Uncu, A.T.; Frary, A.; Doganlar, S. Genome-wide SNP discovery and QTL mapping for fruit quality traits in inbred backcross lines (IBLs) of Solanum pimpinellifolium using genotyping by sequencing. BMC Genom. 2017, 18, 1-10. [CrossRef]

41. Ohlson, E.W.; Ashrafi, H.; Foolad, M.R. Identification and mapping of late blight resistance quantitative trait loci in tomato accession PI 163245. Plant Genome 2018, 11, 180007. [CrossRef]

42. Gonda, I.; Ashrafi, H.; Lyon, D.A.; Strickler, S.R.; Hulse-Kemp, A.M.; Ma, Q.; Sun, H.; Stoffel, K.; Powell, A.F.; Futrell, S.; et al. Sequencing-based bin map construction of a tomato mapping population, facilitating high-resolution quantitative trait loci detection. Plant Genome 2019, 12, 1-14. [CrossRef]

43. Lin, Y.-P.; Liu, C.-Y.; Chen, K.-Y. Assessment of genetic differentiation and linkage disequilibrium in Solanum pimpinellifolium using genome-wide high-density SNP markers. G3 Genes Genomes Genet. 2019, 9, 1497-1505. [CrossRef]

44. Acquadro, A.; Barchi, L.; Gramazio, P.; Portis, E.; Vilanova, S.; Comino, C.; Plazas, M.; Prohens, J.; Lanteri, S. Coding SNPs analysis highlights genetic relationships and evolution pattern in eggplant complexes. PLoS ONE 2017, 12, e0180774. [CrossRef]

45. Edae, E.A.; Olivera, P.D.; Jin, Y.; Rouse, M.N. Genotyping-by-sequencing facilitates a high-density consensus linkage map forAegilops umbellulata, a wild relative of cultivated wheat. G3 Genes Genomes Genet. 2017, 7, 1551-1561. [CrossRef]

46. Guo, X.; Cericola, F.; Fè, D.; Pedersen, M.G.; Lenk, I.; Jensen, C.S.; Jensen, J.; Janss, L.L. Genomic prediction in tetraploid ryegrass using allele frequencies based on genotyping by sequencing. Front. Plant Sci. 2018, 9, 1165. [CrossRef]

47. Hussain, W.; Baenziger, P.S.; Belamkar, V.; Guttieri, M.J.; Venegas, J.P.; Easterly, A.; Sallam, A.; Poland, J. Genotyping-bysequencing derived high-density linkage map and its application to QTL mapping of flag leaf traits in bread wheat. Sci. Rep. 2017, 7, 16394. [CrossRef] [PubMed]

48. Yao, C.; Chen, G.; Song, C.; Keefe, J.; Mendelson, M.; Huan, T.; Sun, B.B.; Laser, A.; Maranville, J.C.; Wu, H.; et al. Genome-wide mapping of plasma protein QTLs identifies putatively causal genes and pathways for cardiovascular disease. Nat. Commun. 2018, 9, 1-11. [CrossRef]

49. Jin, Y.; Zhao, W.; Nie, S.; Liu, S.-S.; El-Kassaby, Y.A.; Wang, X.-R.; Mao, J.-F. Genome-wide variant identification and high-density genetic map construction using RADseq for Platycladus orientalis (Cupressaceae). G3 Genes Genomes Genet. 2019, 9, $3663-3672$. [CrossRef] [PubMed]

50. Qi, P.; Eudy, D.; Schnable, J.C.; Schmutz, J.; Raymer, P.L.; Devos, K.M. High density genetic maps of Seashore paspalum using genotyping-by-sequencing and their relationship to the sorghum bicolor genome. Sci. Rep. 2019, 9, 12183. [CrossRef]

51. Toppino, L.; Barchi, L.; Mercati, F.; Acciarri, N.; Perrone, D.; Martina, M.; Gattolin, S.; Sala, T.; Fadda, S.; Mauceri, A.; et al. A new intra-specific and high-resolution genetic map of eggplant based on a RIL population, and location of QTLs related to Plant anthocyanin pigmentation and seed vigour. Genes 2020, 11, 745. [CrossRef]

52. Jordon-Thaden, I.E.; Beck, J.B.; Rushworth, C.A.; Windham, M.D.; Diaz, N.; Cantley, J.T.; Martine, C.T.; Rothfels, C.J. A basic dd RAD seq two-enzyme protocol performs well with herbarium and silica-dried tissues across four genera. Appl. Plant Sci. 2020, 8 , e11344. [CrossRef]

53. Sunde, J.; Yıldırım, Y.; Tibblin, P.; Forsman, A. Comparing the performance of microsatellites and RADseq in population genetic studies: Analysis of data for pike (Esox lucius) and a synthesis of previous studies. Front. Genet. 2020, 11, 218. [CrossRef]

54. Tsujimoto, M.; Araki, K.S.; Honjo, M.N.; Yasugi, M.; Nagano, A.J.; Akama, S.; Hatakeyama, M.; Shimizu-Inatsugi, R.; Sese, J.; Shimizu, K.K.; et al. Genet assignment and population structure analysis in a clonal forest-floor herb, Cardamine leucantha, using RAD-seq. AoB Plants 2019, 12. [CrossRef]

55. Feng, J.; Zhao, S.; Li, M.; Zhang, C.; Qu, H.; Li, Q.; Li, J.; Lin, Y.; Pu, Z. Genome-wide genetic diversity detection and population structure analysis in sweetpotato (Ipomoea batatas) using RAD-seq. Genomics 2020, 112, 1978-1987. [CrossRef] 
56. Aflitos, S.A.; Schijlen, E.; De Jong, H.; De Ridder, D.; Smit, S.; Finkers, R.; Wang, J.; Zhang, G.; Li, N.; Mao, L.; et al. Exploring genetic variation in the tomato (Solanumsection Lycopersicon) clade by whole-genome sequencing. Plant J. 2014, 80, 136-148. [CrossRef] [PubMed]

57. Roohanitaziani, R.; De Maagd, R.A.; Lammers, M.; Molthoff, J.; Meijer-Dekens, F.; Van Kaauwen, M.P.W.; Finkers, R.; Tikunov, Y.; Visser, R.G.F.; Bovy, A. Exploration of a resequenced tomato core collection for phenotypic and genotypic variation in Plant growth and fruit quality traits. Genes 2020,11, 1278. [CrossRef]

58. Hirsch, C.N.; Foerster, J.M.; Johnson, J.M.; Sekhon, R.S.; Muttoni, G.; Vaillancourt, B.; Peñagaricano, F.; Lindquist, E.; Pedraza, M.A.; Barry, K.; et al. Insights into the maize pan-genome and pan-transcriptome. Plant Cell 2014, 26, 121-135. [CrossRef] [PubMed]

59. Li, Y.-H.; Zhou, G.; Ma, J.; Jiang, W.; Jin, L.-G.; Zhang, Z.; Guo, Y.; Zhang, J.; Sui, Y.; Zheng, L.; et al. De novo assembly of soybean wild relatives for pan-genome analysis of diversity and agronomic traits. Nat. Biotechnol. 2014, 32, 1045-1052. [CrossRef]

60. Schatz, M.C.; Maron, L.G.; Stein, J.C.; Wences, A.H.; Gurtowski, J.; Biggers, E.; Lee, H.; Kramer, M.; Antoniou, E.; Ghiban, E.; et al. Whole genome de novo assemblies of three divergent strains of rice, Oryza sativa, document novel gene space of aus and indica. Genome Biol. 2014, 15, 1-16. [CrossRef]

61. Golicz, A.A.; Bayer, P.E.; Barker, G.C.; Edger, P.P.; Kim, H.; Martinez, P.A.; Chan, C.-K.K.; Severn-Ellis, A.; McCombie, W.R.; Parkin, I.A.P.; et al. The pangenome of an agronomically important crop Plant Brassica oleracea. Nat. Commun. 2016, 7, 13390. [CrossRef]

62. Song, J.-M.; Guan, Z.; Hu, J.; Guo, C.; Yang, Z.; Wang, S.; Liu, D.; Wang, B.; Lu, S.; Zhou, R.; et al. Eight high-quality genomes reveal pan-genome architecture and ecotype differentiation of Brassica napus. Nat. Plants 2020, 6, 34-45. [CrossRef]

63. Khan, A.W.; Garg, V.; Roorkiwal, M.; Golicz, A.A.; Edwards, D.; Varshney, R.K. Super-pangenome by integrating the wild side of a species for accelerated crop improvement. Trends Plant Sci. 2020, 25, 148-158. [CrossRef] [PubMed]

64. Tettelin, H.; Masignani, V.; Cieslewicz, M.J.; Donati, C.; Medini, D.; Ward, N.L.; Angiuoli, S.V.; Crabtree, J.; Jones, A.L.; Durkin, A.S.; et al. Genome analysis of multiple pathogenic isolates of Streptococcus agalactiae: Implications for the microbial "pan-genome". Proc. Natl. Acad. Sci. USA 2005, 102, 13950-13955. [CrossRef] [PubMed]

65. Alonge, M.; Wang, X.; Benoit, M.; Soyk, S.; Pereira, L.; Zhang, L.; Suresh, H.; Ramakrishnan, S.; Maumus, F.; Ciren, D.; et al. Major impacts of widespread structural variation on gene expression and crop improvement in tomato. Cell 2020, 182, 145-161.e23. [CrossRef]

66. Ou, L.; Li, D.; Lv, J.; Chen, W.; Zhang, Z.; Li, X.; Yang, B.; Zhou, S.; Yang, S.; Li, W.; et al. Pan-genome of cultivated pepper (Capsicum) and its use in gene presence-absence variation analyses. New Phytol. 2018, 220, 360-363. [CrossRef]

67. Chen, G.; Hackett, R.; Walker, D.; Taylor, A.; Lin, Z.; Grierson, D. Identification of a specific isoform of tomato lipoxygenase (TomloxC) involved in the generation of fatty acid-derived flavor compounds. Plant Physiol. 2004, 136, 2641-2651. [CrossRef]

68. Shen, J.; Tieman, D.; Jones, J.B.; Taylor, M.G.; Schmelz, E.; Huffaker, A.; Bies, D.; Chen, K.; Klee, H.J. A 13-lipoxygenase, TomloxC, is essential for synthesis of C5 flavour volatiles in tomato. J. Exp. Bot. 2014, 65, 419-428. [CrossRef] [PubMed]

69. Yang, W.; Guo, Z.; Huang, C.; Duan, L.; Chen, G.; Jiang, N.; Fang, W.; Feng, H.; Xie, W.; Lian, X.; et al. Combining high-throughput phenotyping and genome-wide association studies to reveal natural genetic variation in rice. Nat. Commun. 2014, 5. [CrossRef] [PubMed]

70. Yang, J.; Jiang, H.; Yeh, C.; Yu, J.; Jeddeloh, J.A.; Nettleton, D.; Schnable, P.S. Extreme-phenotype genome-wide association study (XP-GWAS): A method for identifying trait-associated variants by sequencing pools of individuals selected from a diversity panel. Plant J. 2015, 84, 587-596. [CrossRef]

71. Minamikawa, M.F.; Takada, N.; Terakami, S.; Saito, T.; Onogi, A.; Kajiya-Kanegae, H.; Hayashi, T.; Yamamoto, T.; Iwata, H. Genome-wide association study and genomic prediction using parental and breeding populations of Japanese pear (Pyrus pyrifolia Nakai). Sci. Rep. 2018, 8, 11994. [CrossRef]

72. Mir, R.R.; Reynolds, M.; Pinto, F.; Khan, M.A.; Bhat, M.A. High-throughput phenotyping for crop improvement in the genomics era. Plant Sci. 2019, 282, 60-72. [CrossRef]

73. Visscher, P.M.; Wray, N.R.; Zhang, Q.; Sklar, P.; McCarthy, M.I.; Brown, M.A.; Yang, J. 10 Years of GWAS discovery: Biology, function, and translation. Am. J. Hum. Genet. 2017, 101, 5-22. [CrossRef] [PubMed]

74. Sauvage, C.; Segura, V.; Bauchet, G.; Stevens, R.; Do, P.T.; Nikoloski, Z.; Fernie, A.R.; Causse, M. Genome-wide association in tomato reveals 44 candidate loci for fruit metabolic traits. Plant Physiol. 2014, 165, 1120-1132. [CrossRef]

75. Zhang, J.; Zhao, J.; Xu, Y.; Liang, J.; Chang, P.; Yan, F.; Li, M.; Liang, Y.; Zou, Z. Genome-wide association mapping for tomato volatiles positively contributing to tomato flavor. Front. Plant Sci. 2015, 6, 6. [CrossRef]

76. Bauchet, G.; Grenier, S.; Samson, N.; Bonnet, J.; Grivet, L.; Causse, M. Use of modern tomato breeding germplasm for deciphering the genetic control of agronomical traits by genome wide association study. Theor. Appl. Genet. 2017, 130, 875-889. [CrossRef]

77. Zhao, J.; Sauvage, C.; Zhao, J.; Bitton, F.; Bauchet, G.; Liu, D.; Huang, S.; Tieman, D.M.; Klee, H.J.; Causse, M. Meta-analysis of genome-wide association studies provides insights into genetic control of tomato flavor. Nat. Commun. 2019, 10, 1-12. [CrossRef] [PubMed]

78. Phan, N.T.; Trinh, L.T.; Rho, M.-Y.; Park, T.-S.; Kim, O.-R.; Zhao, J.; Kim, H.-M.; Sim, S.-C. Identification of loci associated with fruit traits using genome-wide single nucleotide polymorphisms in a core collection of tomato (Solanum lycopersicum L.). Sci. Hortic. 2019, 243, 567-574. [CrossRef] 
79. Ye, J.; Li, W.; Ai, G.; Li, C.; Liu, G.; Chen, W.; Wang, B.; Wang, W.; Lu, Y.; Zhang, J.; et al. Genome-wide association analysis identifies a natural variation in basic helix-loop-helix transcription factor regulating ascorbate biosynthesis via D-mannose/Lgalactose pathway in tomato. PLoS Genet. 2019, 15, e1008149. [CrossRef] [PubMed]

80. Gao, N.; Teng, J.; Ye, S.; Yuan, X.; Huang, S.; Zhang, H.; Zhang, X.; Li, J.; Zhang, Z. Genomic prediction of complex phenotypes using genic similarity based relatedness matrix. Front. Genet. 2018, 9, 364. [CrossRef] [PubMed]

81. Daetwyler, H.D.; Calus, M.P.L.; Pong-Wong, R.; Campos, G.D.L.; Hickey, J.M. Genomic prediction in animals and plants: Simulation of data, validation, reporting, and benchmarking. Genetics 2013, 193, 347-365. [CrossRef] [PubMed]

82. Yamamoto, E.; Matsunaga, H.; Onogi, A.; Kajiya-Kanegae, H.; Minamikawa, M.; Suzuki, A.; Shirasawa, K.; Hirakawa, H.; Nunome, T.; Yamaguchi, H.; et al. A simulation-based breeding design that uses whole-genome prediction in tomato. Sci. Rep. 2016, 6. [CrossRef]

83. Tusell, L.; Pérez-Rodríguez, P.; Forni, S.; Wu, X.-L.; Gianola, D. Genome-enabled methods for predicting litter size in pigs: A comparison. Animal 2013, 7, 1739-1749. [CrossRef]

84. Ni, G.; Cavero, D.; Fangmann, A.; Erbe, M.; Simianer, H. Whole-genome sequence-based genomic prediction in laying chickens with different genomic relationship matrices to account for genetic architecture. Genet. Sel. Evol. 2017, 49, 8. [CrossRef] [PubMed]

85. Duenk, P.; Calus, M.P.L.; Wientjes, Y.C.J.; Breen, V.P.; Henshall, J.; Hawken, R.J.; Bijma, P. Validation of genomic predictions for body weight in broilers using crossbred information and considering breed-of-origin of alleles. Genet. Sel. Evol. 2019, 51, 1-12. [CrossRef]

86. Pandey, M.K.; Chaudhari, S.; Jarquin, D.; Janila, P.; Crossa, J.; Patil, S.C.; Sundravadana, S.; Khare, D.; Bhat, R.S.; Radhakrishnan, T.; et al. Genome-based trait prediction in multi-environment breeding trials in groundnut. Theor. Appl. Genet. 2020, 133, 3101-3117. [CrossRef]

87. Lenz, P.; Nadeau, S.; Azaiez, A.; Gérardi, S.; DesLauriers, M.; Perron, M.; Isabel, N.; Beaulieu, J.; Bousquet, J. Genomic prediction for hastening and improving efficiency of forward selection in conifer polycross mating designs: An example from white spruce. Heredity 2020, 124, 562-578. [CrossRef]

88. Robertsen, C.D.; Hjortshøj, R.L.; Janss, L. Genomic selection in cereal breeding. Agronomy 2019, 9, 95. [CrossRef]

89. Cortés, A.J.; Restrepo-Montoya, M.; Bedoya-Canas, L.E. Modern strategies to assess and breed forest tree adaptation to changing climate. Front. Plant Sci. 2020, 11. [CrossRef] [PubMed]

90. Saliba-Colombani, V.; Causse, M.; Langlois, D.; Philouze, J.; Buret, M. Genetic analysis of organoleptic quality in fresh market tomato. 1. Mapping QTLs for physical and chemical traits. Theor. Appl. Genet. 2001, 102, 259-272. [CrossRef]

91. Fulton, T.; Bucheli, P.; Voirol, E.; Lopez, J.; Pétiard, V.; Tanksley, S. Quantitative trait loci (QTL) affecting sugars, organic acids and other biochemical properties possibly contributing to flavor, identified in four advanced backcross populations of tomato. Euphytica 2002, 127, 163-177. [CrossRef]

92. Tadmor, Y.; Fridman, E.; Gur, A.; Larkov, O.; Lastochkin, E.; Ravid, U.; Zamir, D.; Lewinsohn, E. Identification of malodorous, a wild species allele affecting tomato aroma that was selected against during domestication. J. Agric. Food Chem. 2002, 50, 2005-2009. [CrossRef] [PubMed]

93. Tieman, D.M.; Zeigler, M.; Schmelz, E.A.; Taylor, M.G.; Bliss, P.; Kirst, M.; Klee, H.J. Identification of loci affecting flavour volatile emissions in tomato fruits. J. Exp. Bot. 2006, 57, 887-896. [CrossRef]

94. Kochevenko, A.; Fernie, A.R. The genetic architecture of branched-chain amino acid accumulation in tomato fruits. J. Exp. Bot. 2011, 62, 3895-3906. [CrossRef]

95. Ruggieri, V.; Francese, G.; Sacco, A.; D’Alessandro, A.; Rigano, M.M.; Parisi, M.; Milone, M.; Cardi, T.; Mennella, G.; Barone, A.; et al. An association mapping approach to identify favourable alleles for tomato fruit quality breeding. BMC Plant Biol. 2014, 14, 1-15. [CrossRef]

96. Capel, C.; Fernández-Del-Carmen, A.; Alba, J.M.; Lima-Silva, V.; Gras, F.H.; Salinas, M.; Boronat, A.; Angosto, T.; Botella, J.R.; Fernández-Muñoz, R.; et al. Wide-genome QTL mapping of fruit quality traits in a tomato RIL population derived from the wild-relative species Solanum pimpinellifolium L. Theor. Appl. Genet. 2015, 128, 2019-2035. [CrossRef] [PubMed]

97. Zhao, J.; Xu, Y.; Ding, Q.; Huang, X.; Zhang, Y.; Zou, Z.; Li, M.; Cui, L.; Zhang, J. Association mapping of main tomato fruit sugars and organic acids. Front. Plant Sci. 2016, 7. [CrossRef]

98. Ebaldina, S.; Picarella, M.E.; Troise, A.D.; Epucci, A.; Eruggieri, V.; Eferracane, R.; Ebarone, A.; Efogliano, V.; Mazzucato, A. Metabolite profiling of italian tomato landraces with different fruit types. Front. Plant Sci. 2016, 7. [CrossRef]

99. Bauchet, G.; Grenier, S.; Samson, N.; Segura, V.; Kende, A.; Beekwilder, J.; Cankar, K.; Gallois, J.; Gricourt, J.; Bonnet, J.; et al. Identification of major loci and genomic regions controlling acid and volatile content in tomato fruit: Implications for flavor improvement. New Phytol. 2017, 215, 624-641. [CrossRef] [PubMed]

100. Garbowicz, K.; Liu, Z.; Alseekh, S.; Tieman, D.; Taylor, M.; Kuhalskaya, A.; Ofner, I.; Zamir, D.; Klee, H.J.; Fernie, A.R.; et al. Quantitative trait loci analysis identifies a prominent gene involved in the production of fatty acid-derived flavor volatiles in tomato. Mol. Plant 2018, 11, 1147-1165. [CrossRef]

101. Kimbara, J.; Ohyama, A.; Chikano, H.; Ito, H.; Hosoi, K.; Negoro, S.; Miyatake, K.; Yamaguchi, H.; Nunome, T.; Fukuoka, H.; et al. QTL mapping of fruit nutritional and flavor components in tomato (Solanum lycopersicum) using genome-wide SSR markers and recombinant inbred lines (RILs) from an intra-specific cross. Euphytica 2018, 214, 210. [CrossRef] 
102. Tikunov, Y.; Roohanitaziani, R.; Meijer-Dekens, F.; Molthoff, J.; Paulo, J.; Finkers, R.; Capel, I.; Moreno, F.C.; Maliepaard, C.; Vries, M.N.; et al. The genetic and functional analysis of flavor in commercial tomato: The FLORAL4 gene underlies a QTL for floral aroma volatiles in tomato fruit. Plant J. 2020, 103, 1189-1204. [CrossRef]

103. Zouine, M.; Maza, E.; Djari, A.; Lauvernier, M.; Frasse, P.; Smouni, A.; Pirrello, J.; Bouzayen, M. TomExpress, a unified tomato RNA-Seq platform for visualization of expression data, clustering and correlation networks. Plant J. 2017, 92, 727-735. [CrossRef] [PubMed]

104. Fall, R.; Karl, T.; Hansel, A.; Jordan, A.; Lindinger, W. Volatile organic compounds emitted after leaf wounding: On-line analysis by proton-transfer-reaction mass spectrometry. J. Geophys. Res. Space Phys. 1999, 104, 15963-15974. [CrossRef]

105. Ferrie, B. The cloning of two tomato lipoxygenase genes and their differential expression during fruit ripening. Plant Physiol. 1994, 106, 109-118. [CrossRef] [PubMed]

106. Jansen, G.A.; Wanders, R.J. $\alpha$-Oxidation. Biochim. Biophys. Acta BBA Bioenerg. 2006, 1763, 1403-1412. [CrossRef] [PubMed]

107. Li, C.; Schilmiller, A.L.; Liu, G.; Lee, G.I.; Jayanty, S.; Sageman, C.; Vrebalov, J.; Giovannoni, J.J.; Yagi, K.; Kobayashi, Y.; et al. Role of $\beta$-Oxidation in Jasmonate biosynthesis and systemic wound signaling in tomato. Plant Cell 2005, 17, 971-986. [CrossRef] [PubMed]

108. Liavonchanka, A.; Feussner, I. Lipoxygenases: Occurrence, functions and catalysis. J. Plant Physiol. 2006, 163, 348-357. [CrossRef] [PubMed]

109. Prestage, S.; Linforth, R.S.; Taylor, A.; Lee, E.; Speirs, J.; Schuch, W. Volatile production in tomato fruit with modified alcohol dehydrogenase activity. J. Sci. Food Agric. 1999, 79, 131-136. [CrossRef]

110. Matsui, K. Green leaf volatiles: Hydroperoxide lyase pathway of oxylipin metabolism. Curr. Opin. Plant Biol. 2006, 9, 274-280. [CrossRef]

111. Chen, H.; Cao, S.; Jin, Y.; Tang, Y.; Qi, H. The relationship between CmADHs and the diversity of volatile organic compounds of three aroma types of melon (Cucumis melo). Front. Physiol. 2016, 7, 254. [CrossRef]

112. Vieira, D.D.S.S.; Emiliani, G.; Michelozzi, M.; Centritto, M.; Luro, F.; Morillon, R.; Loreto, F.; Gesteira, A.S.; Maserti, B. Polyploidization alters constitutive content of volatile organic compounds (VOC) and improves membrane stability under water deficit in Volkamer lemon (Citrus limonia Osb.) leaves. Environ. Exp. Bot. 2016, 126, 1-9. [CrossRef]

113. Zhou, Z.; Wu, Q.; Yao, Z.; Deng, H.; Liu, B.; Yue, C.; Deng, T.; Lai, Z.; Sun, Y. Dynamics of ADH and related genes responsible for the transformation of $C$ 6-aldehydes to C 6-alcohols during the postharvest process of oolong tea. Food Sci. Nutr. 2019, 8, 104-113. [CrossRef]

114. Furuhashi, T.; Ishii, R.; Onishi, H.; Ota, S. Elucidation of biochemical pathways underlying VOCs production in A549 cells. Front. Mol. Biosci. 2020, 7, 116. [CrossRef]

115. Domínguez, T.; Hernández, M.L.; Pennycooke, J.C.; Jiménez, P.; Martínez-Rivas, J.M.; Sanz, C.; Stockinger, E.J.; Sánchez-Serrano, J.J.; Sanmartín, M. Increasing $\omega-3$ desaturase expression in tomato results in altered aroma profile and enhanced resistance to cold stress. Plant Physiol. 2010, 153, 655-665. [CrossRef]

116. Speirs, J.; Lee, E.; Holt, K.; Yong-Duk, K.; Scott, N.S.; Loveys, B.; Schuch, W. Genetic manipulation of alcohol dehydrogenase levels in ripening tomato fruit affects the balance of some flavor aldehydes and alcohols. Plant Physiol. 1998, 117, 1047-1058. [CrossRef] [PubMed]

117. Moummou, H.; Kallberg, Y.; Tonfack, L.B.; Persson, B.; Van Der Rest, B. The Plant short-chain dehydrogenase (SDR) superfamily: Genome-wide inventory and diversification patterns. BMC Plant Biol. 2012, 12, 219. [CrossRef] [PubMed]

118. Gosset, V.; Harmel, N.; Göbel, C.; Francis, F.; Haubruge, E.; Wathelet, J.-P.; Du Jardin, P.; Feussner, I.; Fauconnier, M.-L. Attacks by a piercing-sucking insect (Myzus persicae Sultzer) or a chewing insect (Leptinotarsa decemlineata Say) on potato plants (Solanum tuberosum L.) induce differential changes in volatile compound release and oxylipin synthesis. J. Exp. Bot. 2009, 60, 1231-1240. [CrossRef]

119. Campestre, C.; Angelini, G.; Gasbarri, C.; Angerosa, F. The compounds responsible for the sensory profile in monovarietal virgin olive oils. Molecules 2017, 22, 1833. [CrossRef] [PubMed]

120. Vong, W.C.; Liu, S.-Q. Bioconversion of green volatiles in okara (Soybean residue) into esters by coupling enzyme catalysis and yeast (Lindnera saturnus) fermentation. Appl. Microbiol. Biotechnol. 2018, 102, 10017-10026. [CrossRef]

121. Mariutto, M.; Duby, F.; Adam, A.; Bureau, C.; Fauconnier, M.-L.; Ongena, M.; Thonart, P.; Dommes, J. The elicitation of a systemic resistance by Pseudomonas putida BTP1 in tomato involves the stimulation of two lipoxygenase isoforms. BMC Plant Biol. 2011, 11, 29. [CrossRef]

122. Longhurst, T.J.; Tung, H.F.; Brady, C.J. Developmental Regulation of the Expression of Alcohol Dehydrogenase in Ripening Tomato Fruits. J. Food Biochem. 1990, 14, 421-433. [CrossRef]

123. Van Der Straeten, D.; Rodrigues-Pousada, R.A.; Gielen, J.; Van Montagu, M. Tomato alcohol dehydrogenase: Expression during fruit ripening and under hypoxic conditions. FEBS Lett. 1991, 295, 39-42. [CrossRef]

124. Buttery, R.G.; Teranishi, R.; Flath, R.A.; Ling, L.C. Identification of additional tomato paste volatiles. J. Agric. Food Chem. 1990, 38, 792-795. [CrossRef]

125. Brosnan, J.T.; Brosnan, M.E. Branched-chain amino acids: Enzyme and substrate regulation. J. Nutr. 2006, 136, 207S-211S. [CrossRef] [PubMed]

126. Schuster, J.; Binder, S. The mitochondrial branched-chain aminotransferase (AtBCAT-1) is capable to initiate degradation of leucine, isoleucine and valine in almost all tissues in Arabidopsis thaliana. Plant Mol. Biol. 2005, 57, 241-254. [CrossRef] [PubMed] 
127. Maloney, G.S.; Kochevenko, A.; Tieman, D.M.; Tohge, T.; Krieger, U.; Zamir, D.; Taylor, M.G.; Fernie, A.R.; Klee, H.J. Characterization of the branched-chain amino acid aminotransferase enzyme family in tomato. Plant Physiol. 2010, 153, 925-936. [CrossRef] [PubMed]

128. Kochevenko, A.; Klee, H.J.; Fernie, A.R.; Araújo, W.L. Molecular identification of a further branched-chain aminotransferase 7 (BCAT7) in tomato plants. J. Plant Physiol. 2012, 169, 437-443. [CrossRef]

129. Tohge, T.; Alseekh, S.; Fernie, A.R. On the regulation and function of secondary metabolism during fruit development and ripening. J. Exp. Bot. 2013, 65, 4599-4611. [CrossRef]

130. Marilley, L. Flavours of cheese products: Metabolic pathways, analytical tools and identification of producing strains. Int. J. Food Microbiol. 2004, 90, 139-159. [CrossRef]

131. Mooney, B.P.; Miernyk, J.A.; Randall, D.D. Thecomplexfate of $\alpha$-ketoacids. Annu. Rev. Plant Biol. 2002, 53, 357-375. [CrossRef]

132. Simkin, A.J.; Schwartz, S.H.; Auldridge, M.; Taylor, M.G.; Klee, H.J. The tomato carotenoid cleavage dioxygenase 1 genes contribute to the formation of the flavor volatiles $\beta$-ionone, pseudoionone, and geranylacetone. Plant J. 2004, 40, 882-892. [CrossRef]

133. Wei, Y.; Wan, H.; Wu, Z.; Wang, R.; Ruan, M.; Ye, Q.; Li, Z.; Zhou, G.; Yao, Z.; Yang, Y.; et al. A comprehensive analysis of carotenoid cleavage dioxygenases genes in Solanum lycopersicum. Plant Mol. Biol. Rep. 2015, 34, 512-523. [CrossRef]

134. Floss, D.S.; Walter, M.H. Role of carotenoid cleavage dioxygenase 1 (CCD1) in apocarotenoid biogenesis revisited. Plant Signal. Behav. 2009, 4, 172-175. [CrossRef]

135. Vogel, J.T.; Tan, B.-C.; Mccarty, D.R.; Klee, H.J. The carotenoid cleavage dioxygenase 1 enzyme has broad substrate specificity, cleaving multiple carotenoids at two different bond positions. J. Biol. Chem. 2008, 283, 11364-11373. [CrossRef] [PubMed]

136. Lashbrooke, J.G.; Young, P.R.; Dockrall, S.J.; Vasanth, K.; A Vivier, M. Functional characterisation of three members of the Vitis vinifera L. carotenoid cleavage dioxygenase gene family. BMC Plant Biol. 2013, 13, 156. [CrossRef]

137. Frusciante, S.; Diretto, G.; Bruno, M.; Ferrante, P.; Pietrella, M.; Prado-Cabrero, A.; Rubio, A.-M.; Beyer, P.D.; Gomez-Gomez, L.; Al-Babili, S.; et al. Novel carotenoid cleavage dioxygenase catalyzes the first dedicated step in saffron crocin biosynthesis. Proc. Natl. Acad. Sci. USA 2014, 111, 12246-12251. [CrossRef]

138. Ilg, A.; Bruno, M.; Beyer, P.; Al-Babili, S. Tomato carotenoid cleavage dioxygenases 1A and 1B: Relaxed double bond specificity leads to a plenitude of dialdehydes, mono-apocarotenoids and isoprenoid volatiles. FEBS Open Bio 2014, 4, 584-593. [CrossRef]

139. Qin, X.; Fischer, K.; Yu, S.; Dubcovsky, J.; Tian, L. Distinct expression and function of carotenoid metabolic genes and homoeologs in developing wheat grains. BMC Plant Biol. 2016, 16, 155. [CrossRef]

140. Klee, H.J. Improving the flavor of fresh fruits: Genomics, biochemistry, and biotechnology. New Phytol. 2010, 187, 44-56. [CrossRef] [PubMed]

141. Simpson, K.; Quiroz, L.F.; Rodriguez-Concepción, M.; Stange, C. Differential contribution of the first two enzymes of the MEP pathway to the supply of metabolic precursors for carotenoid and chlorophyll biosynthesis in carrot (Daucus carota). Front. Plant Sci. 2016, 7. [CrossRef] [PubMed]

142. Manoharan, R.K.; Jung, H.-J.; Hwang, I.; Jeong, N.; Kho, K.H.; Chung, M.-Y.; Nou, I.S. Molecular breeding of a novel orange-brown tomato fruit with enhanced $\beta$-carotene and chlorophyll accumulation. Hereditas 2017, 154, 1. [CrossRef]

143. Enfissi, E.M.; Nogueira, M.; Bramley, P.M.; Fraser, P. The regulation of carotenoid formation in tomato fruit. Plant J. 2017, 89, 774-788. [CrossRef] [PubMed]

144. Liu, L.; Shao, Z.; Zhang, M.; Wang, Q. Regulation of carotenoid metabolism in tomato. Mol. Plant 2015, 8, 28-39. [CrossRef] [PubMed]

145. García-Alcázar, M.; Giménez, E.; Pineda, B.; Capel, C.; García-Sogo, B.; Sánchez, S.; Yuste-Lisbona, F.J.; Angosto, T.; Capel, J.; Moreno, V.; et al. Albino T-DNA tomato mutant reveals a key function of 1-deoxy-D-xylulose-5-phosphate synthase (DXS1) in Plant development and survival. Sci. Rep. 2017, 7, 45333. [CrossRef] [PubMed]

146. D'Andrea, L.; Simon-Moya, M.; Llorente, B.; Llamas, E.; Marro, M.; Loza-Alvarez, P.; Li, L.; Rodríguez-Concepción, M. Interference with Clp protease impairs carotenoid accumulation during tomato fruit ripening. J. Exp. Bot. 2018, 69, 1557-1568. [CrossRef] [PubMed]

147. McQuinn, R.P.; Wong, B.; Giovannoni, J.J. AtPDSoverexpression in tomato: Exposing unique patterns of carotenoid self-regulation and an alternative strategy for the enhancement of fruit carotenoid content. Plant Biotechnol. J. 2018, 16, 482-494. [CrossRef] [PubMed]

148. Chetelat, R.T.; Qin, X.; Tan, M.; Burkart-Waco, D.; Moritama, Y.; Huo, X.; Wills, T.; Pertuzé, R. Introgression lines of Solanum sitiens a wild nightshade of the Atacama Desert, in the genome of cultivated tomato. Plant J. 2019, 100, 836-850. [CrossRef]

149. Xiong, C.; Luo, D.; Lin, A.; Zhang, C.; Shan, L.; He, P.; Li, B.; Zhang, Q.; Hua, B.; Yuan, Z.; et al. A tomato B-box proteinSlBBX20 modulates carotenoid biosynthesis by directly activatingPHYTOENE SYNTHASE 1, and is targeted for 26S proteasome-mediated degradation. New Phytol. 2019, 221, 279-294. [CrossRef]

150. Britton, G.; Pfander, H.; Liaaen-Jensen, S. Carotenoids; Birkhäuser Verlag: Basel, Switzerland, 1998; Volume 3.

151. Galpaz, N.; Wang, Q.; Menda, N.; Zamir, D.; Hirschberg, J. Abscisic acid deficiency in the tomato mutant high-pigment 3 leading to increased plastid number and higher fruit lycopene content. Plant J. 2008, 53, 717-730. [CrossRef]

152. Mann, V.; Pecker, I.; Hirschberg, J. Cloning and characterization of the gene for phytoene desaturase (Pds) from tomato (Lycopersicon esculentum). Plant Mol. Biol. 1994, 24, 429-434. [CrossRef] 
153. Pecker, I.; Gabbay, R.; Cunningham, F.X.; Hirschberg, J. Cloning and characterization of the cDNA for lycopene $\beta$-cyclase from tomato reveals decrease in its expression during fruit ripening. Plant Mol. Biol. 1996, 30, 807-819. [CrossRef]

154. Ronen, G.; Carmel-Goren, L.; Zamir, D.; Hirschberg, J. An alternative pathway to $\beta$-carotene formation in plant chromoplasts discovered by map-based cloning of Beta and old-gold color mutations in tomato. Proc. Natl. Acad. Sci. USA 2000, 97, 11102-11107. [CrossRef] [PubMed]

155. Lois, L.M.; Rodriguez-Concepcion, M.; Gallego, F.; Campos, N.; Boronat, A. Carotenoid biosynthesis during tomato fruit development: Regulatory role of 1-deoxy-D-xylulose 5-phosphate synthase. Plant J. 2000, 22, 503-513. [CrossRef] [PubMed]

156. Bartley, G.E.; Scolnik, P.A. cDNA cloning, expression during development, and genome mapping of PSY2, a second tomato gene encoding phytoene synthase. J. Biol. Chem. 1993, 268, 25718-25721. [CrossRef]

157. Fraser, P.D.; Truesdale, M.R.; Bird, C.R.; Schuch, W.; Bramley, P.M. Carotenoid biosynthesis during tomato fruit development (Evidence for tissue-specific gene expression). Plant Physiol. 1994, 105, 405-413. [CrossRef]

158. Fraser, P.D.; Enfissi, E.M.; Halket, J.M.; Truesdale, M.R.; Yu, D.; Gerrish, C.; Bramley, P.M. Manipulation of phytoene levels in tomato fruit: Effects on isoprenoids, plastids, and intermediary metabolism. Plant Cell 2007, 19, 3194-3211. [CrossRef]

159. Giorio, G.; Stigliani, A.L.; D'Ambrosio, C. Phytoene synthase genes in tomato (Solanumlycopersicum, L.) -new data on the structures, the deduced amino acid sequences and the expression patterns. FEBS J. 2007, 275, 527-535. [CrossRef]

160. Rodríguez-Villalón, A.; Gas, E.; Rodríguez-Concepción, M. Phytoene synthase activity controls the biosynthesis of carotenoids and the supply of their metabolic precursors in dark-grown Arabidopsis seedlings. Plant J. 2009, 60, 424-435. [CrossRef]

161. Isaacson, T.; Ronen, G.; Zamir, D.; Hirschberg, J. Cloning of tangerine from tomato reveals a carotenoid isomerase essential for the production of $\beta$-carotene and xanthophylls in plants. Plant Cell 2002, 14, 333-342. [CrossRef]

162. Ronen, G.; Cohen, M.; Zamir, D.; Hirschberg, J. Regulation of carotenoid biosynthesis during tomato fruit development: Expression of the gene for lycopene epsilon-cyclase is down-regulated during ripening and is elevated in the mutant delta. Plant $J$. 1999, 17, 341-351. [CrossRef] [PubMed]

163. Apel, W.; Bock, R. Enhancement of carotenoid biosynthesis in transplastomic tomatoes by induced Lycopene-to-Provitamin a conversion. Plant Physiol. 2009, 151, 59-66. [CrossRef] [PubMed]

164. D'Ambrosio, C.; Stigliani, A.L.; Giorio, G. Overexpression of CrtR-b2 (carotene $\beta$ hydroxylase 2) from S. lycopersicum L. differentially affects xanthophyll synthesis and accumulation in transgenic tomato plants. Transgenic Res. 2010, 20, 47-60. [CrossRef]

165. Gonzalez-Jorge, S.; Mehrshahi, P.; Magallanes-Lundback, M.; Lipka, A.E.; Angelovici, R.; Gore, M.A.; DellaPenna, D. zeaxanthin epoxidase activity potentiates carotenoid degradation in maturing seed. Plant Physiol. 2016, 171, 1837-1851. [CrossRef]

166. Alder, A.; Jamil, M.; Marzorati, M.; Bruno, M.; Vermathen, M.; Bigler, P.; Ghisla, S.; Bouwmeester, H.; Beyer, P.; Al-Babili, S.; et al. The path from-carotene to carlactone, a strigolactone-like plant hormone. Science 2012, 335, 1348-1351. [CrossRef]

167. Huang, F.-C.; Molnár, P.; Schwab, W. Cloning and functional characterization of carotenoid cleavage dioxygenase 4 genes. J. Exp. Bot. 2009, 60, 3011-3022. [CrossRef]

168. Campbell, R.; Ducreux, L.J.; Morris, W.L.; Morris, J.A.; Suttle, J.C.; Ramsay, G.; Bryan, G.J.; Hedley, P.E.; Taylor, M.A. The metabolic and developmental roles of carotenoid cleavage dioxygenase4 from potato. Plant Physiol. 2010, 154, 656-664. [CrossRef]

169. Brandi, F.; Bar, E.; Mourgues, F.; Horváth, G.; Turcsi, E.; Giuliano, G.; Liverani, A.; Tartarini, S.; Lewinsohn, E.; Rosati, C. Study of "Redhaven" peach and its white-fleshed mutant suggests a key role of CCD4 carotenoid dioxygenase in carotenoid and norisoprenoid volatile metabolism. BMC Plant Biol. 2011, 11, 24. [CrossRef]

170. Jang, S.-J.; Jeong, H.-B.; Jung, A.; Kang, M.-Y.; Kim, S.; Ha, S.-H.; Kwon, J.-K.; Kang, B.-C. Phytoene synthase 2 can compensate for the absence of PSY1 in the control of color in Capsicum fruit. J. Exp. Bot. 2020, 71, 3417-3427. [CrossRef]

171. Fantini, E.; Falcone, G.; Frusciante, S.; Giliberto, L.; Giuliano, G. Dissection of tomato Lycopene biosynthesis through virus-induced gene silencing. Plant Physiol. 2013, 163, 986-998. [CrossRef] [PubMed]

172. Tzin, V.; Galili, G. New insights into the shikimate and aromatic amino acids biosynthesis pathways in plants. Mol. Plant 2010, 3 , 956-972. [CrossRef] [PubMed]

173. Sakai, M.; Hirata, H.; Sayama, H.; Sekiguchi, K.; Itano, H.; Asai, T.; Dohra, H.; Hara, M.; Watanabe, N. Production of 2Phenylethanol in roses as the dominant floral scent compound fromL-phenylalanine by two key enzymes, a PLP-dependent decarboxylase and a phenylacetaldehyde reductase. Biosci. Biotechnol. Biochem. 2007, 71, 2408-2419. [CrossRef]

174. Xie, Q.; Liu, Z.; Meir, S.; Rogachev, I.; Aharoni, A.; Klee, H.J.; Galili, G. Altered metabolite accumulation in tomato fruits by coexpressing a feedback-insensitive AroG and the Ph ODO 1 MYB-type transcription factor. Plant Biotechnol. J. 2016, 14, 2300-2309. [CrossRef] [PubMed]

175. Tieman, D.M.; Loucas, H.M.; Kim, J.Y.; Clark, D.G.; Klee, H.J. Tomato phenylacetaldehyde reductases catalyze the last step in the synthesis of the aroma volatile 2-phenylethanol. Phytochemistry 2007, 68, 2660-2669. [CrossRef] [PubMed]

176. Costa, M.A.; Marques, J.V.; Dalisay, D.S.; Herman, B.; Bedgar, D.L.; Davin, L.B.; Lewis, N.G. Transgenic hybrid poplar for sustainable and scalable production of the commodity/specialty chemical, 2-Phenylethanol. PLoS ONE 2013, 8, e83169. [CrossRef] [PubMed]

177. Liu, P.; Cheng, Y.; Yang, M.; Liu, Y.; Chen, K.; Long, C.-A.; Deng, X. Mechanisms of action for 2-phenylethanol isolated from Kloeckera apiculata in control of Penicillium molds of citrus fruits. BMC Microbiol. 2014, 14. [CrossRef] [PubMed]

178. Singh, R.; Rastogi, S.; Dwivedi, U.N. Phenylpropanoid metabolism in ripening fruits. Compr. Rev. Food Sci. Food Saf. 2010, 9 , 398-416. [CrossRef]

179. Vogt, T. Phenylpropanoid biosynthesis. Mol. Plant 2010, 3, 2-20. [CrossRef] [PubMed] 
180. Fraser, C.M.; Chapple, C. The phenylpropanoid pathway in arabidopsis. Arab. Book 2011, 9, e0152. [CrossRef]

181. Biała, W.; Jasiński, M. The phenylpropanoid case-it is transport that matters. Front. Plant Sci. 2018, 9, 9. [CrossRef]

182. Koeduka, T.; Fridman, E.; Gang, D.R.; Vassão, D.G.; Jackson, B.L.; Kish, C.M.; Orlova, I.; Spassova, S.M.; Lewis, N.G.; Noel, J.P.; et al. Eugenol and isoeugenol, characteristic aromatic constituents of spices, are biosynthesized via reduction of a coniferyl alcohol ester. Proc. Natl. Acad. Sci. USA 2006, 103, 10128-10133. [CrossRef]

183. Tieman, D.; Zeigler, M.; Schmelz, E.; Taylor, M.G.; Rushing, S.; Jones, J.B.; Klee, H.J. Functional analysis of a tomato salicylic acid methyl transferase and its role in synthesis of the flavor volatile methyl salicylate. Plant J. 2010, 62, 113-123. [CrossRef]

184. Mageroy, M.H.; Tieman, D.M.; Floystad, A.; Taylor, M.G.; Klee, H.J. A Solanum lycopersicum catechol-O-methyltransferase involved in synthesis of the flavor molecule guaiacol. Plant J. 2012, 69, 1043-1051. [CrossRef]

185. Tikunov, Y.; Molthoff, J.; De Vos, R.C.; Beekwilder, J.; Van Houwelingen, A.; Van Der Hooft, J.J.; Vries, M.N.-D.; Labrie, C.W.; Verkerke, W.; Van De Geest, H.; et al. Non-smoky glycosyltransferase1 prevents the release of smoky aroma from tomato fruit. Plant Cell 2013, 25, 3067-3078. [CrossRef]

186. Klee, H.J.; Tieman, D.M. The genetics of fruit flavour preferences. Nat. Rev. Genet. 2018, 19, 347-356. [CrossRef]

187. Rigano, M.M.; Raiola, A.; Docimo, T.; Ruggieri, V.; Calafiore, R.; Vitaglione, P.; Ferracane, R.; Frusciante, L.; Barone, A. Metabolic and molecular changes of the phenylpropanoid pathway in tomato (Solanum lycopersicum) lines carrying different Solanum pennellii wild chromosomal regions. Front. Plant Sci. 2016, 7. [CrossRef] [PubMed]

188. Kim, A.Y.; Kim, H.M.; Ma, S.H.; Park, S.Y.; Dat, M.T.; Jang, G.; Joung, Y.H. The promoter of tomato Histidine decarboxylase A is fruit-specific, and its expression is stably maintained in fruits during ripening. Plant Biotechnol. Rep. 2019, 13, 43-50. [CrossRef]

189. Kumar, R. Evolutionary trails of plant group ii pyridoxal phosphate-dependent decarboxylase genes. Front. Plant Sci. $2016,7$. [CrossRef] [PubMed]

190. Wellenreuther, M.; Mérot, C.; Berdan, E.; Bernatchez, L. Going beyond SNPs: The role of structural genomic variants in adaptive evolution and species diversification. Mol. Ecol. 2019, 28, 1203-1209. [CrossRef] [PubMed]

191. Guo, J.; Cao, K.; Deng, C.; Li, Y.; Zhu, G.; Fang, W.; Chen, C.; Wang, X.; Wu, J.; Guan, L.; et al. An integrated peach genome structural variation map uncovers genes associated with fruit traits. Genome Biol. 2020, 21, 258. [CrossRef] [PubMed]

192. Zhang, Z.; Mao, L.; Chen, H.; Bu, F.; Li, G.; Sun, J.; Li, S.; Sun, H.; Jiao, C.; Blakely, R.; et al. Genome-wide mapping of structural variations reveals a copy number variant that determines reproductive morphology in cucumber. Plant Cell 2015, 27, 1595-1604. [CrossRef]

193. Shen, X.; Liu, Z.-Q.; Mocoeur, A.; Xia, Y.; Jing, H.-C. PAV markers in Sorghum bicolour: Genome pattern, affected genes and pathways, and genetic linkage map construction. Theor. Appl. Genet. 2015, 128, 623-637. [CrossRef] [PubMed]

194. McHale, L.K.; Haun, W.J.; Xu, W.W.; Bhaskar, P.B.; Anderson, J.E.; Hyten, D.L.; Gerhardt, D.J.; Jeddeloh, J.A.; Stupar, R.M. Structural variants in the soybean genome localize to clusters of biotic stress-response genes. Plant Physiol. 2012, 159, 1295-1308. [CrossRef] [PubMed]

195. Gabur, I.; Chawla, H.S.; Lopisso, D.T.; Von Tiedemann, A.; Snowdon, R.J.; Obermeier, C. Gene presence-absence variation associates with quantitative Verticillium longisporum disease resistance in Brassica napus. Sci. Rep. 2020, 10, 4131. [CrossRef] [PubMed]

196. Salgotra, R.K.; Stewart, C.N. Functional markers for precision Plant breeding. Int. J. Mol. Sci. 2020, 21, 4792. [CrossRef] [PubMed]

197. Fu, Y.-B.; Yang, M.-H.; Zeng, F.; Biligetu, B. Searching for an accurate marker-based prediction of an individual quantitative trait in molecular plant breeding. Front. Plant Sci. 2017, 8, 1182. [CrossRef] [PubMed] 